Supporting Information

\title{
Revealing the Dynamic Process of Ion Pair Recognition by Calix[4]pyrrole: A Case Study of Cesium Chloride
}

\author{
Teng Wang, ${ }^{* a}$ Jingjing Liu, ${ }^{b}$ and Xiaoqun $\mathrm{Cao}^{a}$
}

*Corresponding author E-mail: wangt@sdfmu.edu.cn

${ }^{a}$ School of Chemistry and Pharmaceutical Engineering, Shandong First Medical University \& Shandong Academy of Medical Sciences, Taian, 271016, P.R. China

${ }^{b}$ School of Chemistry and Chemical Engineering, Taishan University, Taian, 271021, P.R. China 


\section{Table of Contents}

\section{Computational Details}

AIMD Simulations

QM Calculations

SAPT Calculations

Wavefunction Analysis

2. Results and Discussion

Dynamic Binding Behavior

Solute-Solvent Interactions

Driving Forces

Charge-Transfer

3. References

4. Coordinates 


\section{Computational Details}

\section{AIMD Simulations}

The initial coordinates of 1,3-alternate conformation of CP were taken from the experimental crystal structure. ${ }^{1}$ One $\mathrm{CP}$ molecule, one $\mathrm{Cl}^{-}$anion, and one $\mathrm{Cs}^{+}$cation were immersed in a cubic box with an edge length of $15 \AA$ containing randomly placed 30 dichloromethane $\left(\mathrm{CH}_{2} \mathrm{Cl}_{2}\right)$ solvent molecules using the Packmol program. ${ }^{2}$ The box volumes were adjusted to match the experimental density of $\mathrm{CH}_{2} \mathrm{Cl}_{2}$ ( $\rho=$ $1.33 \mathrm{~g} \mathrm{~cm}^{-3}$ at $\mathrm{T}=293 \mathrm{~K}$ ). This cubic box defines a harmonic repulsive wall around the system and helps to keep all molecules inside of the box. AIMD simulations were run using the Born-Oppenheimer molecular dynamics (BOMD) simulations model. ${ }^{3}$ The dynamics were performed employing the dispersion-corrected BLYP ${ }^{4,5}$ D3 $^{6,7}$ method including geometrical counterpoise (gCP) correction ${ }^{8}$ combined with the def2-SVP ${ }^{9}$ basis set. The resolution-of-the-identity (RI) approximation ${ }^{10,11}$ with the def2/J auxiliary basis set ${ }^{12}$ was applied to speed up the Coulomb term (J) calculation. The temperature was maintained at $300 \mathrm{~K}$, using Berendsen thermostat method ${ }^{13}$ with a time constant of $10 \mathrm{fs}$. The equations of motion were integrated using the velocity Verlet algorithm ${ }^{14}$ with a time step of $0.5 \mathrm{fs}$, and a 10 ps simulation was carried out. All AIMD simulations were performed using the ORCA 4.2 program. ${ }^{15}$ Coordinates were saved every 10 fs for analysis, and the trajectories were visualized and analyzed using the VMD 1.9 program. ${ }^{16}$

\section{QM Calculations}

Several typical solute-solvent interaction models of $\mathrm{Cs}^{+}: \mathrm{CP}: \mathrm{Cl}^{-}$with $0-5 \mathrm{CH}_{2} \mathrm{Cl}_{2}$ molecules were extracted from the AIMD trajectories. Then, the above models and $\mathrm{Cs}^{+}: \mathrm{CP}$ complex were fully optimized at the $\omega$ B97X-D ${ }^{17} / \mathrm{def} 2-\mathrm{SVP}$ level. The vibrational frequencies were also computed at the same level of theory, and no imaginary frequency is found for these optimized geometries. Based on the optimized geometries, the interaction energy was calculated at the $\omega$ B97X-D/def2-TZVPD ${ }^{18}$ level, and the basis sets superposition error (BSSE) correction was taken into account using the counterpoise correction method. ${ }^{19}$ Rigid potential energy surface (PES) 
scans were performed at the $\omega \mathrm{B} 97 \mathrm{X}-\mathrm{D} / \mathrm{def} 2-\mathrm{TZVPD}$ level for $\mathrm{Cs}^{+}: \mathrm{CP}: \mathrm{Cl}^{-}$and $\mathrm{Cs}^{+}: \mathrm{CP}$ complexes. For $\mathrm{Cs}^{+}: \mathrm{CP}: \mathrm{Cl}^{-}$complex, $\mathrm{Cl}^{-}$and $\cdot \mathrm{Cs}^{+}$were placed on the $\mathrm{z}$ axis, and $\mathrm{CP}$ and $\mathrm{Cl}^{-}$were kept fixed throughout the scan. Then $\mathrm{Cs}^{+}$moved away from $\mathrm{Cl}^{-}$along the $\mathrm{z}$ axis, and their distance increased from 2.0 to $8.0 \AA$ with a step size of $0.2 \AA$. For $\mathrm{Cs}^{+}: \mathrm{CP}$ complex, a dummy atom was added and located at $2.34 \AA$ from the hydrogen atoms of the $\mathrm{NH}$ groups. Dummy atom and $\cdot \mathrm{Cs}^{+}$were placed on the $\mathrm{z}$ axis, and $\mathrm{CP}$ and dummy atom were kept fixed throughout the scan. Then $\mathrm{Cs}^{+}$moved away from dummy atom along the $z$ axis, and their distance increased from 2.0 to $8.0 \AA$ with a step size of $0.2 \AA$. Furthermore, the BSSE-corrected interaction energy between $\mathrm{Cs}^{+}$ and $\mathrm{CP}: \mathrm{Cl}^{-}$in $\mathrm{Cs}^{+}: \mathrm{CP}: \mathrm{Cl}^{-}$complex was calculated using the supermolecule approach at the $\omega$ B97X-D/def2-TZVPD level, and the distance between $\mathrm{Cs}^{+}$and $\mathrm{Cl}^{-}$was varied from 3.0 to $7.0 \AA$ with an increment of $0.4 \AA$. Meanwhile, the interaction energy between $\mathrm{Cs}^{+}$and $\mathrm{CP}$ in $\mathrm{Cs}^{+}: \mathrm{CP}: \mathrm{Cl}^{-}$complex was also obtained in the similar way, and $\mathrm{Cl}^{-}$was removed in the corresponding geometry. In addition, PES scans were performed at the $\operatorname{CCSD}(\mathrm{T})^{20} / \operatorname{def} 2-\mathrm{QZVPD}, \quad \operatorname{CCSD}(\mathrm{T}) / \operatorname{def} 2-\mathrm{TZVPD}$, and $\omega \mathrm{B} 97 \mathrm{X}-\mathrm{D} / \mathrm{def} 2-\mathrm{TZVPD}$ levels for the $\mathrm{Cs}^{+}: \mathrm{Cl}^{-}$ion pair by varying their distance. The distance between $\mathrm{Cl}^{-}$and $\mathrm{Cs}^{+}$was scanned from 2.0 to $8.0 \AA$ with a step size of $0.2 \AA$. All QM calculations were performed using the Gaussian 09 D.01 program ${ }^{21}$ and visualized through the GaussView 5 program. ${ }^{22}$

\section{SAPT Calculations}

The intermolecular interaction energy can be decomposed into four physically meaningful terms, i.e., electrostatic, induction, dispersion, and exchange terms by SAPT. ${ }^{23-27}$ To explore the contributions of NCI in the process of ion pair recognition, SAPT calculations based on the QM optimized geometries were performed as follows. First, the SAPT interaction energy between $\mathrm{Cs}^{+}: \mathrm{CP}: \mathrm{Cl}^{-}$and $\mathrm{CH}_{2} \mathrm{Cl}_{2}$ solvent molecules was calculated at the SAPT0/def2-TZVPD level. Then, the SAPT interaction energy scans were obtained by varying the distance between $\mathrm{Cs}^{+}$and $\mathrm{Cl}^{-}$or dummy atom, and all atoms except for $\mathrm{Cs}^{+}$were kept fixed during the scan. The parameter settings including variable, initial value, number of steps, and step size of SAPT scans were 
similar to those used for the above-mentioned PES scans. The $\mathrm{Cs}^{+} \cdots \mathrm{CP} \mathrm{Cl}^{-}$and $\mathrm{Cs}^{+} \cdots \mathrm{CP}$ interaction energy was scanned at the SAPT0/def2-TZVPD level. In addition, the $\mathrm{Cs}^{+} \cdots \mathrm{Cl}^{-}$interaction energy was scanned at the SAPT2+(3) $\delta \mathrm{MP} 2 /$ def2-QZVPD, $\quad$ SAPT2+(3) $\delta \mathrm{MP} 2 /$ def2-TZVPD, $\quad$ and SAPT0/def2-TZVPD levels. Density fitting (DF) approximations ${ }^{28}$ were applied to SAPT to enhance the efficiency. All SAPT calculations were performed using the PSI4 program. ${ }^{29}$

\section{Wavefunction Analysis}

The topological analysis of the electron density $(\rho)$ was carried out for solute-solvent interaction models using the AIM methodology. ${ }^{30,31}$ According to Bader's method, the special points where the gradient of the electron density $(\nabla \rho)$ vanishes are called critical points (CPs), and the bond critical points (BCPs) are often viewed as the most important points between two interacting atoms. The CPs were searched and located using the Multiwfn 3.6 program. ${ }^{32}$

The NCI analysis was performed to visualize the NCI in ion pair recognition. NCI can be isolated as regions with low density and low reduced gradient. ${ }^{33}$ The value of the function of electron density multiplied by the sign of the second Hessian eigenvalue, viz., $\operatorname{sign}\left(\lambda_{2}\right) \rho$, can be represented by colors and mapped onto reduced density gradient (RDG, RDG $(r)=\frac{1}{2\left(3 \pi^{2}\right)^{1 / 3}} \frac{|\nabla \rho(r)|}{\rho(r)^{4 / 3}}$ ) isosurfaces by the Multiwfn 3.6 program, and the type and strength of NCI can be displayed by the VMD 1.9 program.

The $\mathrm{CDA}^{34,35}$ was used to quantitatively investigate the charge-transfer between fragments in $\mathrm{Cs}^{+}: \mathrm{CP}: \mathrm{Cl}^{-}$complex. The CDA constructs the wave function of the complex in terms of the linear combination of the donor and acceptor fragment orbitals, and three terms $d, b$ and $r$ are calculated. The term $d$ is the charge donation from donor to acceptor, and the term $b$ is the charge back donation from acceptor to donor. The term $r$ is the charge polarization or repulsive polarization from the overlapping area. The CDA was performed employing a generalized CDA method ${ }^{36}$ as implemented in the Multiwfn 3.6 program. 


\section{Results and Discussion}

\section{Dynamic Binding Behavior}

(a)

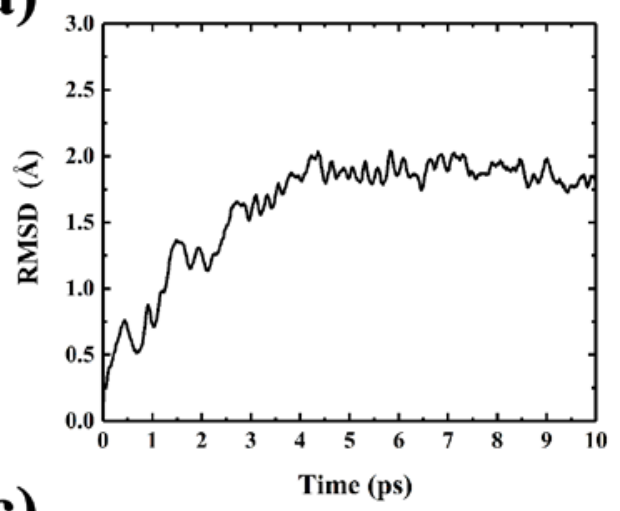

(c)

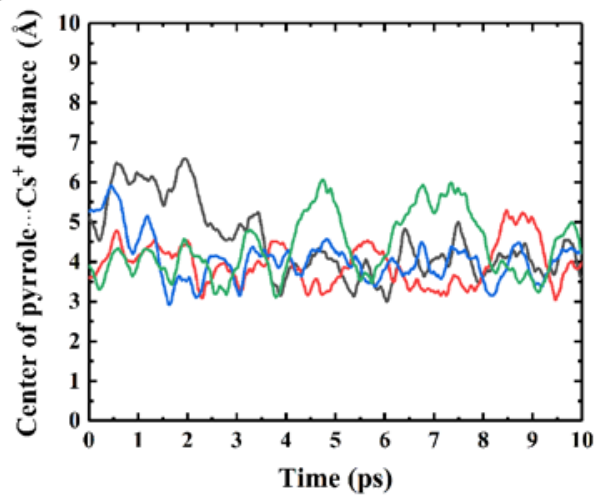

(b)

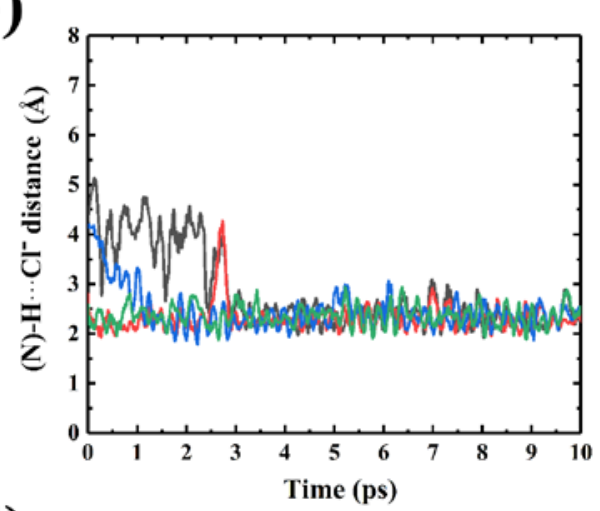

(d)

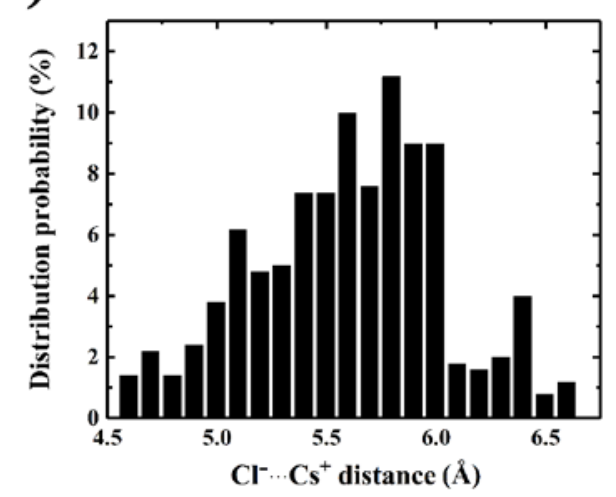

Figure S1. (a) Distance RMSD over the atoms of CP from the starting structure as a function of time. (b) Time evolution of distances between $\mathrm{H}$ connected to $\mathrm{N}^{-}$and $\mathrm{Cl}^{-}$. (c) Time evolution of distances between centers of pyrrole rings and $\mathrm{Cs}^{+}$. (d) Distribution of distances between $\mathrm{Cl}^{-}$and $\mathrm{Cs}^{+}$based on the last 5 ps trajectories of the simulations. 


\section{Solute-Solvent Interactions}

To investigate the interactions between ions and solvent, the radial distribution functions (RDFs) for the atom pairs of ions-solvent were calculated based on the last 5 ps AIMD trajectories and plotted in Figure S2. The first peak at a distance of $2.65 \AA$ in the $\mathrm{Cl}^{-}-\mathrm{H}$ RDFs corresponds to weak interactions between them. While the first peak emerges at a large distance of $3.85 \AA$ in the $\mathrm{Cl}^{-}-\mathrm{Cl}$ RDFs, indicating that the interactions between them can be neglected. Contrary to $\mathrm{Cl}^{-}$, the $\mathrm{Cs}^{+}-\mathrm{H} / \mathrm{Cl} \mathrm{RDFs}$ show that there are no obvious interactions of $\mathrm{Cs}^{+}$with the former due to their large interaction distance while weak interactions with the latter.

To confirm the number of solvent molecules that interact with ions, hydrogen atoms of solvent molecules within $3.5 \AA$ of $\mathrm{Cl}^{-}$and chlorine atoms of solvent molecules within $3.5 \AA$ of $\mathrm{Cs}^{+}$were searched simultaneously for each frame according to the RDFs analysis above based on the last 5 ps AIMD trajectories. Then the solvent molecules that interact with ions can be found by the searched atoms. The solute-solvent interaction models are named $X Y$ according to the number of solvent molecules that interact with $\mathrm{Cs}^{+}(X)$ and $\mathrm{Cl}^{-}(Y)$ respectively. The percentage occurrence of each solute-solvent interaction model was computed, as shown in Figure S3. The maximum numbers of solvent molecules that interact with $\mathrm{Cs}^{+}$and $\mathrm{Cl}^{-}$ are both 3, and the numbers of solvent molecules range from 0 to 5 in interaction models. All possible interaction models were optimized in QM calculations, and the models with $X=3$ were not considered because they make up a small percentage of the whole structures. In addition, although model 23 was not found in the trajectories, it was constructed based on model 22 and also optimized in QM calculations to ensure the integrality of the models. The optimized structures of solute-solvent interaction models are represented in Figure 2, and the corresponding structural parameters are gathered in Table S1 and Table S2.

As presented in Table $\mathrm{S} 1$, each $\mathrm{CH}_{2} \mathrm{Cl}_{2}$ provides one hydrogen to interact with $\mathrm{Cl}^{-}$, and the distances between them range from 2.47 to $2.75 \AA$, in agreement with the RDFs analysis. Meanwhile, the distances between $\mathrm{Cs}^{+}$and chlorine of $\mathrm{CH}_{2} \mathrm{Cl}_{2}$ are $c a$. 
$3.70 \AA$, which is also consistent with RDFs analysis. The only exception is model 20 where one chlorine is $5.45 \AA$ away from $\mathrm{Cs}^{+}$. As shown in Table S2, there is little difference in the corresponding distances between models containing solvent molecules and model 00 , indicating that the solvent does not significantly influence the binding of ion pair to CP from the viewpoint of geometry.

To analyze and visualize the NCI between solvent and CP-ion pair complexes, the gradient isosurfaces of RDG for all models containing solvent molecules are reported in Figure S4 and Figure S5. Green isosurfaces lie between hydrogen of $\mathrm{CH}_{2} \mathrm{Cl}_{2}$ and $\mathrm{Cl}^{-}$, and they can be identified as (C) $-\mathrm{H} \cdots \mathrm{Cl}$ hydrogen bonding interactions. Meanwhile, there are green isosurfaces between chlorine of $\mathrm{CH}_{2} \mathrm{Cl}_{2}$ and

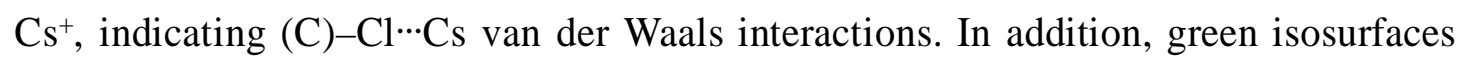
between $\mathrm{CH}_{2} \mathrm{Cl}_{2}$ and $\mathrm{CP}$ can be detected, suggesting that there exist van der Waals interactions. In brief, all the above mentioned NCI are relatively weak.

To further investigate the NCI between CP-ion pair complexes and solvent, the topological analysis of the electron density $(\rho)$ was carried out and the topological properties for selected bond critical points (BCPs) at the $\mathrm{H}\left(\mathrm{CH}_{2} \mathrm{Cl}_{2}\right) \cdots \mathrm{Cl}^{-}$and $\mathrm{Cl}\left(\mathrm{CH}_{2} \mathrm{Cl}_{2}\right) \cdots \mathrm{Cs}^{+}$contacts are gathered in Table S3. As shown in Table S3, these BCPs are characterized by the small values of the $\rho b$ (less than 0.02 a.u.) and the positive Laplacian of the electron density $\nabla^{2} \rho_{b}$. In addition, the $\left|\lambda_{1}\right| / \lambda_{3}$ are less than 1 (range from 0.1 to 0.3 ), and the $\left|V_{b}\right| / G_{b}$ of $\mathrm{H} \cdots \mathrm{Cl}^{-}$and $\mathrm{Cl} \cdots \mathrm{Cs}^{+}$are slightly larger than 1.0 and 0.8 respectively. All these indicate that they are typical closed-shell interactions. Moreover, the $\mathrm{H}^{\cdots} \cdot \mathrm{Cl}^{-}$and $\mathrm{Cl} \cdots \mathrm{Cs}^{+}$can be identified as hydrogen bonding and van der Waals interactions respectively according to the classification of interactions based on the AIM parameters, in agreement with the NCI analysis above.

The interaction energy between all molecular/ionic fragments $\left(\mathrm{CP}, \mathrm{Cl}^{-}, \mathrm{Cs}^{+}\right.$, and $\mathrm{CH}_{2} \mathrm{Cl}_{2}$ ) was computed by employing the supermolecule approach for the difference between the energy of the complex and the energy sum of the fragments, as delineated in Figure $3 \mathrm{~b}$ and Table S5. Although the interaction energy originates from complicated combination of the $\mathrm{Cs}^{+}-\mathrm{CP}_{-} \mathrm{Cl}^{-}$interactions, the $\mathrm{Cs}^{+} / \mathrm{CP} / \mathrm{Cl}^{-}-\mathrm{CH}_{2} \mathrm{Cl}_{2}$ 
interactions, and the $\mathrm{CH}_{2} \mathrm{Cl}_{2}-\mathrm{CH}_{2} \mathrm{Cl}_{2}$ interactions, it can still provide very useful information about the interactions between solvent and CP-ion pair complexes to a certain degree. The interaction energy of model 00 that does not contain solvent molecules is $-198.42 \mathrm{kcal} \mathrm{mol}^{-1}$, and it totally comes from the $\mathrm{Cs}^{+}-\mathrm{CP}_{-}-\mathrm{Cl}^{-}$interactions. While the interaction energy of models containing solvent molecules ranges from -204.39 to $-235.05 \mathrm{kcal} \mathrm{mol}^{-1}$, and the interactions involving solvent account for a small proportion of the total interaction energy. Therefore, the interactions between CP-ion pair complexes and solvent are weak, in agreement with the SAPT results. In addition, the negative of the interaction energy increases with the number of solvent molecules in the model. However, the percentage occurrence of models containing more solvent molecules is low in the AIMD simulations due to the thermal motion and the weakness of the interactions between CP-ion pair complexes and solvent molecules. 
(a)



(c)

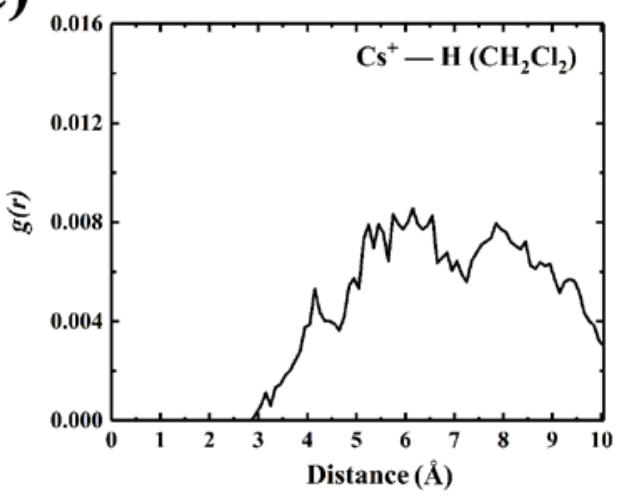

(b)

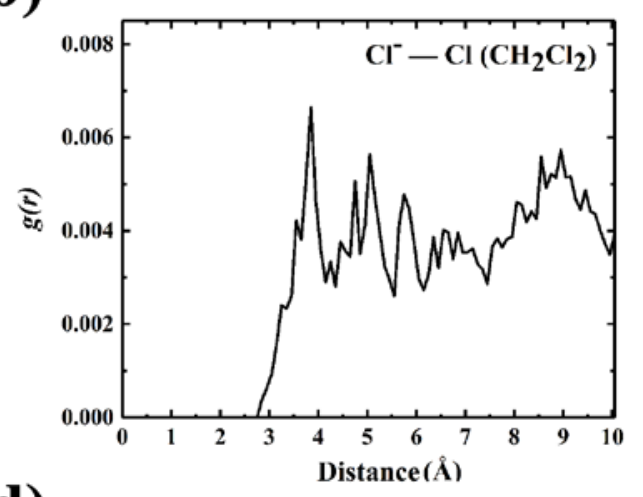

(d)

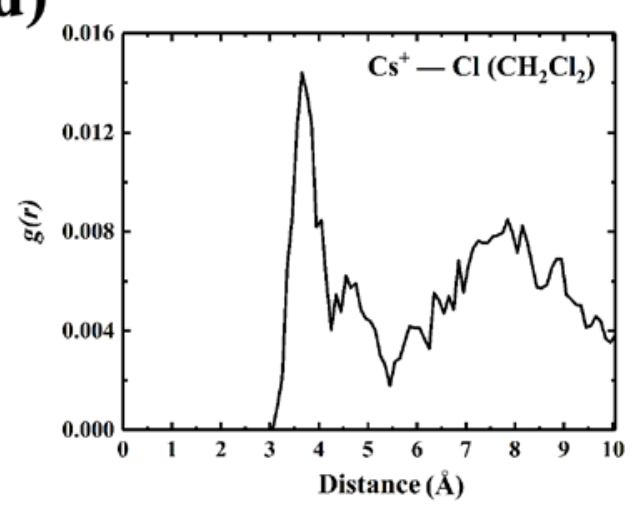

Figure S2. RDFs for the atom pairs of ions-solvent based on the last 5 ps AIMD trajectories. (a) $\mathrm{Cl}^{-}-\mathrm{H}$ RDFs. (b) $\mathrm{Cl}^{-}-\mathrm{Cl}$ RDFs. (c) $\mathrm{Cs}^{+}-\mathrm{H}$ RDFs. (d) $\mathrm{Cs}^{+}-\mathrm{Cl} \mathrm{RDFs}$. 


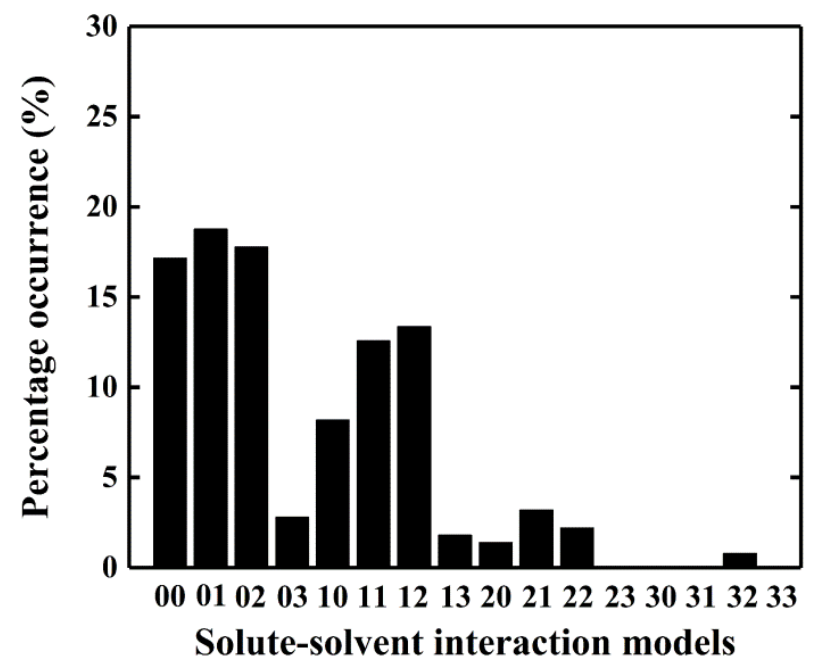

Figure S3. Percentage occurrence of each solute--solvent interaction model. 
Table S1 Selected distances (in $\AA$ ) involving $\mathrm{CH}_{2} \mathrm{Cl}_{2}$ solvent molecules in optimized structures of solute-solvent interaction models. $\mathrm{H}^{\cdots} \mathrm{Cl}^{-}$are the distances between $\mathrm{Cl}^{-}$ and the closest hydrogen of each $\mathrm{CH}_{2} \mathrm{Cl}_{2}$, and $\mathrm{Cl}^{\cdots} \mathrm{Cs}^{+}$are the distances between $\mathrm{Cs}^{+}$ and chlorine of each $\mathrm{CH}_{2} \mathrm{Cl}_{2}$.

\begin{tabular}{|c|c|c|c|c|c|c|c|}
\hline Model & & $\mathrm{H} \cdots \mathrm{Cl}^{-}$ & & \multicolumn{4}{|c|}{$\mathrm{Cl} \cdots \mathrm{Cs}^{+}$} \\
\hline 01 & 2.56 & & & & & & \\
\hline 02 & 2.65 & 2.59 & & & & & \\
\hline 03 & 2.66 & 2.55 & 2.61 & & & & \\
\hline 10 & & & & 3.69 & 3.69 & & \\
\hline 11 & 2.66 & & & 3.72 & 3.71 & & \\
\hline 12 & 2.59 & 2.63 & & 3.71 & 3.67 & & \\
\hline 13 & 2.68 & 2.59 & 2.55 & 3.76 & 3.77 & & \\
\hline 20 & & & & 3.69 & 3.71 & 3.74 & 5.45 \\
\hline 21 & 2.51 & & & 3.71 & 3.70 & 3.75 & 3.73 \\
\hline 22 & 2.51 & 2.69 & & 3.74 & 3.74 & 3.68 & 3.73 \\
\hline 23 & 2.61 & 2.75 & 2.47 & 3.75 & 3.73 & 3.71 & 3.70 \\
\hline
\end{tabular}


Table S2 Selected distances (in $\AA$ ) involving ions in optimized structures of solute-solvent interaction models.

\begin{tabular}{cccccccccc}
\hline Model & \multicolumn{5}{c}{$(\mathrm{N})-\mathrm{H}^{\cdots} \mathrm{Cl}^{-}$} & \multicolumn{5}{c}{ Centers of pyrrole rings $\cdots \mathrm{Cs}^{+}$} & $\mathrm{Cl}^{-\cdots} \mathrm{Cs}^{+}$ \\
\hline 00 & 2.24 & 2.24 & 2.24 & 2.24 & 3.37 & 3.37 & 3.37 & 3.37 & 4.41 \\
01 & 2.26 & 2.27 & 2.28 & 2.26 & 3.37 & 3.38 & 3.36 & 3.37 & 4.45 \\
02 & 2.32 & 2.30 & 2.27 & 2.27 & 3.37 & 3.38 & 3.37 & 3.38 & 4.49 \\
03 & 2.32 & 2.29 & 2.30 & 2.27 & 3.36 & 3.40 & 3.35 & 3.38 & 4.49 \\
10 & 2.24 & 2.24 & 2.24 & 2.21 & 3.35 & 3.37 & 3.35 & 3.47 & 4.42 \\
11 & 2.26 & 2.28 & 2.29 & 2.19 & 3.36 & 3.39 & 3.33 & 3.53 & 4.49 \\
12 & 2.30 & 2.31 & 2.27 & 2.24 & 3.35 & 3.37 & 3.35 & 3.49 & 4.50 \\
13 & 2.34 & 2.31 & 2.30 & 2.28 & 3.34 & 3.36 & 3.40 & 3.45 & 4.54 \\
20 & 2.23 & 2.22 & 2.24 & 2.24 & 3.41 & 3.47 & 3.33 & 3.33 & 4.41 \\
21 & 2.27 & 2.27 & 2.27 & 2.23 & 3.32 & 3.36 & 3.34 & 3.53 & 4.46 \\
22 & 2.27 & 2.28 & 2.34 & 2.26 & 3.35 & 3.37 & 3.33 & 3.49 & 4.48 \\
23 & 2.28 & 2.30 & 2.32 & 2.25 & 3.33 & 3.36 & 3.33 & 3.49 & 4.47 \\
\hline
\end{tabular}



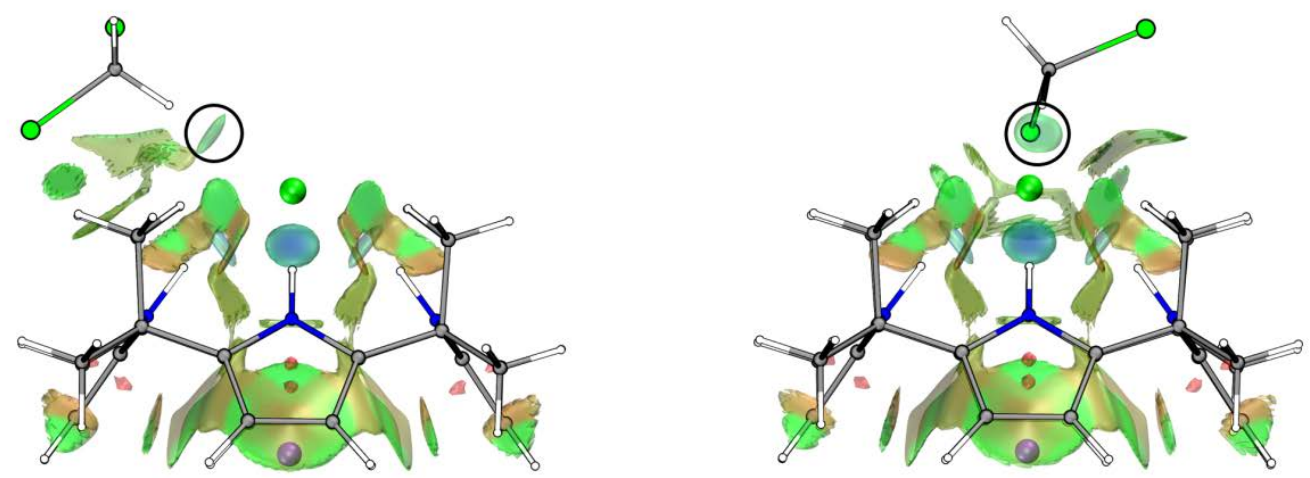

01
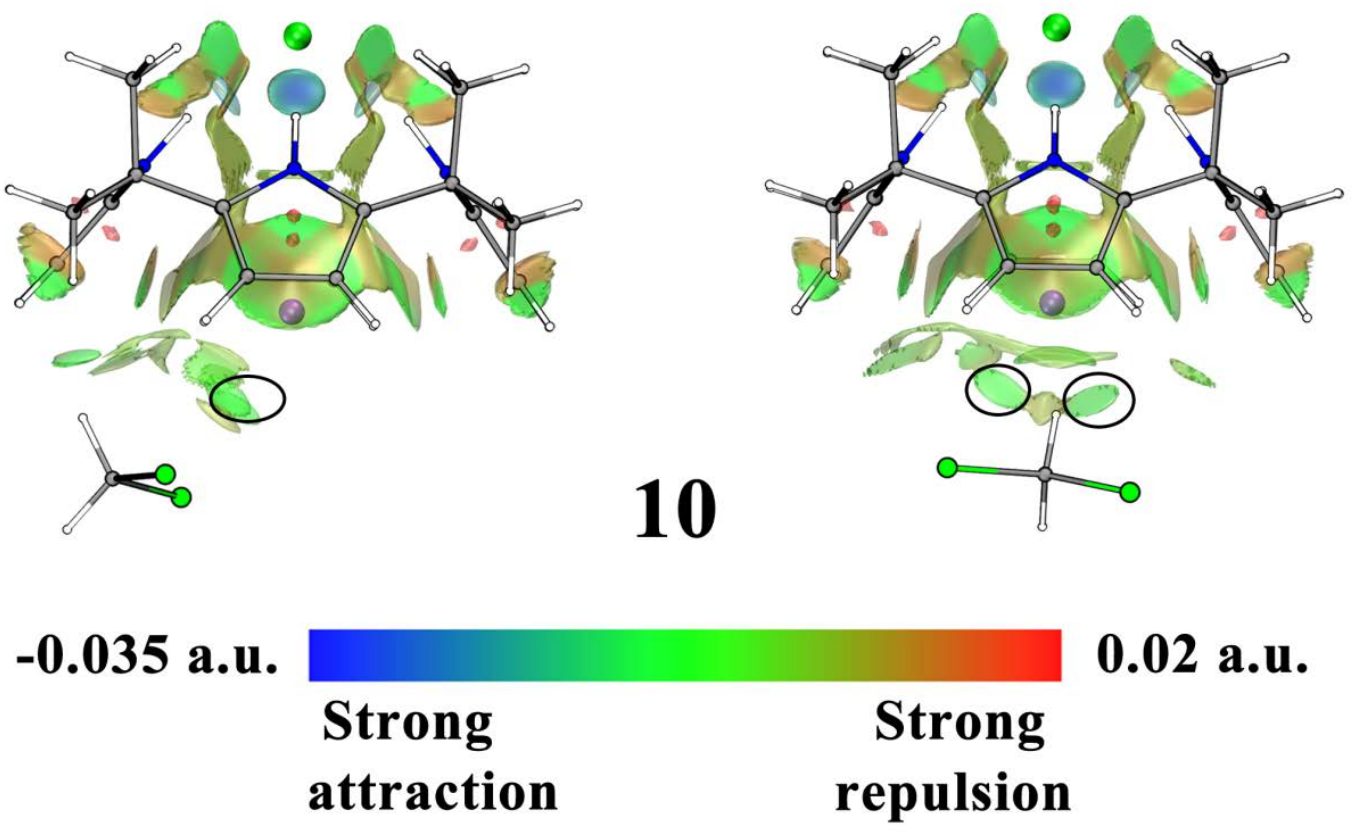

Figure S4. Gradient isosurfaces (RDG $=0.5$ a.u.) for optimized structures of solute-solvent interaction models 01 and 10 . The surfaces are colored on a BGR scale by $\operatorname{sign}\left(\lambda_{2}\right) \rho$ function values. Color code: $\mathrm{C}$, grey; $\mathrm{N}$, blue; $\mathrm{H}$, white; $\mathrm{Cl}$, green; $\mathrm{Cs}$, violet. 


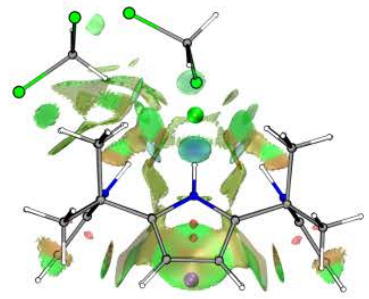

02

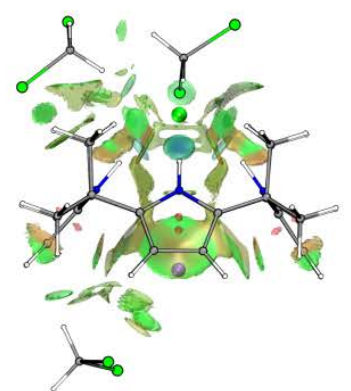

12

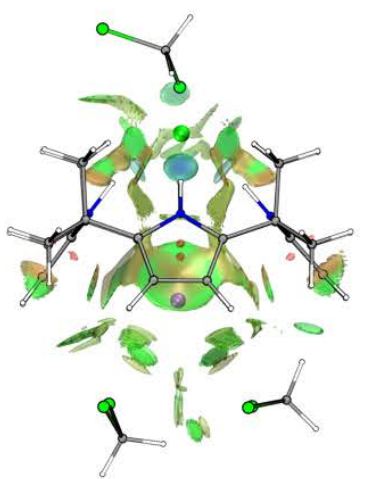

21

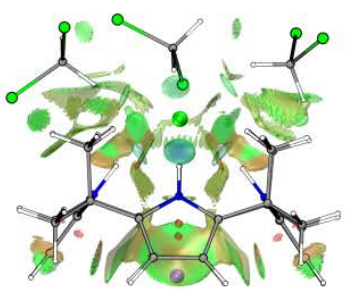

03



13

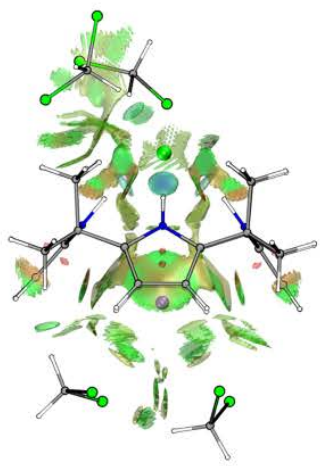

22
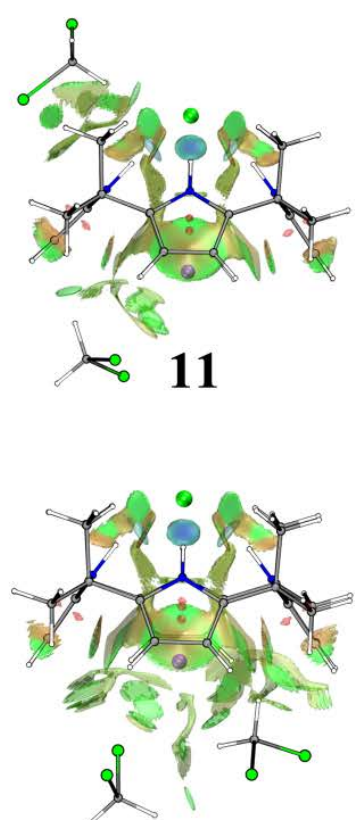

20

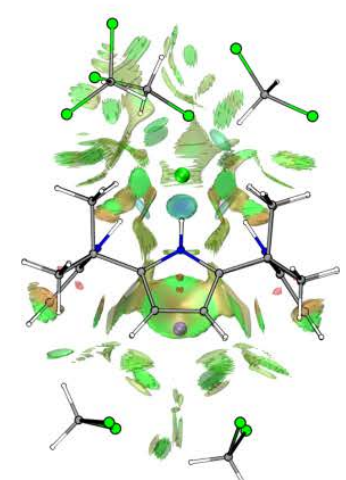

23

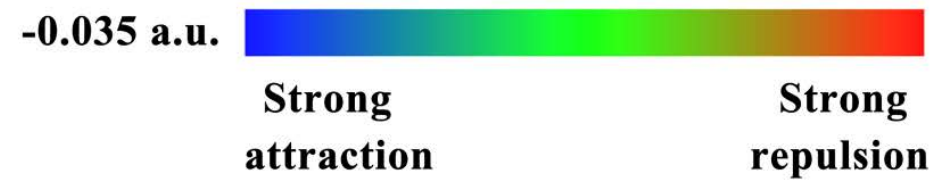

Figure S5. Gradient isosurfaces (RDG $=0.5$ a.u.) for optimized structures of solute-solvent interaction models. The surfaces are colored on a BGR scale by $\operatorname{sign}\left(\lambda_{2}\right) \rho$ function values. Color code: $\mathrm{C}$, grey; $\mathrm{N}$, blue; $\mathrm{H}$, white; $\mathrm{Cl}$, green; $\mathrm{Cs}$, violet. 
Table S3 Topological parameters of the BCPs at the $\mathrm{H}\left(\mathrm{CH}_{2} \mathrm{Cl}_{2}\right) \cdots \mathrm{Cl}^{-}$and $\mathrm{Cl}\left(\mathrm{CH}_{2} \mathrm{Cl}_{2}\right) \cdots \mathrm{Cs}^{+}$contact $\left(\rho_{b}, \nabla^{2} \rho_{b}, G_{b}\right.$, and $V_{b}$ are in a.u.) in solute-solvent interaction models. $G_{b}$ and $V_{b}$ are the Lagrangian kinetic energy and potential energy density at the BCP respectively. $\lambda_{1}$ and $\lambda_{3}$ are the lowest and the highest eigenvalues of Hessian matrix of $\rho_{b}$ respectively.

\begin{tabular}{|c|c|c|c|c|c|c|c|}
\hline Model & Contact & $\rho b$ & $\nabla^{2} \rho_{b}$ & $G_{b}$ & $V_{b}$ & $\left|V_{b}\right| / G_{b}$ & $\left|\lambda_{1}\right| / \lambda_{3}$ \\
\hline 01 & $(\mathrm{C})-\mathrm{H}^{\cdots} \mathrm{Cl}$ & 0.0140 & 0.0317 & 0.0084 & -0.0090 & 1.0714 & 0.2224 \\
\hline 02 & $(\mathrm{C})-\mathrm{H}^{\cdots \cdots} \mathrm{Cl}$ & 0.0133 & 0.0303 & 0.0080 & -0.0085 & 1.0625 & 0.2199 \\
\hline 02 & $(\mathrm{C})-\mathrm{H}^{\cdots} \mathrm{Cl}$ & 0.0118 & 0.0284 & 0.0073 & -0.0075 & 1.0274 & 0.2081 \\
\hline 03 & $(\mathrm{C})-\mathrm{H}^{\cdots} \mathrm{Cl}$ & 0.0117 & 0.0282 & 0.0073 & -0.0074 & 1.0137 & 0.2073 \\
\hline 03 & $(\mathrm{C})-\mathrm{H}^{\cdots} \mathrm{Cl}$ & 0.0142 & 0.0323 & 0.0086 & -0.0092 & 1.0698 & 0.2219 \\
\hline 03 & $(\mathrm{C})-\mathrm{H}^{\cdots} \mathrm{Cl}$ & 0.0128 & 0.0329 & 0.0083 & -0.0084 & 1.0120 & 0.2046 \\
\hline 10 & $(\mathrm{C})-\mathrm{Cl} \cdots \mathrm{Cs}$ & 0.0075 & 0.0239 & 0.0052 & -0.0044 & 0.8462 & 0.1461 \\
\hline 10 & $(\mathrm{C})-\mathrm{Cl} \cdots \mathrm{Cs}$ & 0.0074 & 0.0236 & 0.0051 & -0.0043 & 0.8431 & 0.1451 \\
\hline 11 & $(\mathrm{C})-\mathrm{H}^{\cdots} \mathrm{Cl}$ & 0.0116 & 0.0278 & 0.0072 & -0.0073 & 1.0139 & 0.2080 \\
\hline 11 & $(\mathrm{C})-\mathrm{Cl} \cdots \mathrm{Cs}$ & 0.0070 & 0.0225 & 0.0048 & -0.0040 & 0.8333 & 0.1431 \\
\hline 11 & $(\mathrm{C})-\mathrm{Cl} \cdots \mathrm{Cs}$ & 0.0072 & 0.0230 & 0.0049 & -0.0041 & 0.8367 & 0.1436 \\
\hline 12 & $(\mathrm{C})-\mathrm{H}^{\cdots} \mathrm{Cl}$ & 0.0133 & 0.0304 & 0.0081 & -0.0085 & 1.0494 & 0.2198 \\
\hline 12 & $(\mathrm{C})-\mathrm{H}^{\cdots} \mathrm{Cl}$ & 0.0123 & 0.0293 & 0.0076 & -0.0079 & 1.0395 & 0.2108 \\
\hline 12 & $(\mathrm{C})-\mathrm{Cl} \cdots \mathrm{Cs}$ & 0.0072 & 0.0230 & 0.0049 & -0.0041 & 0.8367 & 0.1440 \\
\hline 12 & $(\mathrm{C})-\mathrm{Cl} \cdots \mathrm{Cs}$ & 0.0078 & 0.0245 & 0.0053 & -0.0045 & 0.8491 & 0.1468 \\
\hline 13 & $(\mathrm{C})-\mathrm{H}^{\cdots} \mathrm{Cl}$ & 0.0113 & 0.0278 & 0.0071 & -0.0072 & 1.0141 & 0.2034 \\
\hline 13 & $(\mathrm{C})-\mathrm{H}^{\cdots} \mathrm{Cl}$ & 0.0132 & 0.0303 & 0.0080 & -0.0084 & 1.0500 & 0.2198 \\
\hline 13 & $(\mathrm{C})-\mathrm{H}^{\cdots} \mathrm{Cl}$ & 0.0142 & 0.0320 & 0.0086 & -0.0091 & 1.0581 & 0.2222 \\
\hline 13 & $(\mathrm{C})-\mathrm{Cl} \cdots \mathrm{Cs}$ & 0.0065 & 0.0212 & 0.0045 & -0.0037 & 0.8222 & 0.1396 \\
\hline 13 & $(\mathrm{C})-\mathrm{Cl} \cdots \mathrm{Cs}$ & 0.0063 & 0.0209 & 0.0044 & -0.0036 & 0.8182 & 0.1385 \\
\hline 20 & $(\mathrm{C})-\mathrm{Cl} \cdots \mathrm{Cs}$ & 0.0072 & 0.0232 & 0.0050 & -0.0041 & 0.8200 & 0.1460 \\
\hline 20 & $(\mathrm{C})-\mathrm{Cl} \cdots \mathrm{Cs}$ & 0.0075 & 0.0240 & 0.0052 & -0.0044 & 0.8462 & 0.1477 \\
\hline 20 & $(\mathrm{C})-\mathrm{Cl} \cdots \mathrm{Cs}$ & 0.0069 & 0.0220 & 0.0047 & -0.0039 & 0.8298 & 0.1409 \\
\hline
\end{tabular}




\begin{tabular}{|c|c|c|c|c|c|c|c|}
\hline Model & Contact & $\rho b$ & $\nabla^{2} \rho_{b}$ & $G_{b}$ & $V_{b}$ & $\left|V_{b}\right| / G_{b}$ & $\left|\lambda_{1}\right| / \lambda_{3}$ \\
\hline 21 & $(\mathrm{C})-\mathrm{H}^{\cdots \cdots} \mathrm{Cl}$ & 0.0153 & 0.0341 & 0.0092 & -0.0099 & 1.0761 & 0.2273 \\
\hline 21 & $(\mathrm{C})-\mathrm{Cl}^{\cdots} \mathrm{Cs}$ & 0.0071 & 0.0228 & 0.0049 & -0.0041 & 0.8367 & 0.1429 \\
\hline 21 & $(\mathrm{C})-\mathrm{Cl} \cdots \mathrm{Cs}$ & 0.0073 & 0.0236 & 0.0051 & -0.0042 & 0.8235 & 0.1439 \\
\hline 21 & $(\mathrm{C})-\mathrm{Cl} \cdots \mathrm{Cs}$ & 0.0069 & 0.0220 & 0.0047 & -0.0039 & 0.8298 & 0.1433 \\
\hline 21 & $(\mathrm{C})-\mathrm{Cl} \cdots \mathrm{Cs}$ & 0.0066 & 0.0214 & 0.0046 & -0.0038 & 0.8261 & 0.1420 \\
\hline 22 & $(\mathrm{C})-\mathrm{H}^{\cdots} \mathrm{Cl}$ & 0.0156 & 0.0358 & 0.0096 & -0.0102 & 1.0625 & 0.2261 \\
\hline 22 & $(\mathrm{C})-\mathrm{H}^{\cdots} \mathrm{Cl}$ & 0.0110 & 0.0276 & 0.0070 & -0.0070 & 1.0000 & 0.2065 \\
\hline 22 & (C) $-\mathrm{Cl} \cdots \mathrm{Cs}$ & 0.0067 & 0.0217 & 0.0046 & -0.0038 & 0.8261 & 0.1422 \\
\hline 22 & (C) $-\mathrm{Cl} \cdots \mathrm{Cs}$ & 0.0068 & 0.0218 & 0.0046 & -0.0038 & 0.8261 & 0.1425 \\
\hline 22 & (C) $-\mathrm{Cl} \cdots \mathrm{Cs}$ & 0.0075 & 0.0240 & 0.0052 & -0.0044 & 0.8462 & 0.1448 \\
\hline 22 & $(\mathrm{C})-\mathrm{Cl} \cdots \mathrm{Cs}$ & 0.0068 & 0.0221 & 0.0047 & -0.0039 & 0.8298 & 0.1420 \\
\hline 23 & $(\mathrm{C})-\mathrm{H}^{\cdots} \mathrm{Cl}$ & 0.0129 & 0.0317 & 0.0082 & -0.0085 & 1.0366 & 0.2129 \\
\hline 23 & $(\mathrm{C})-\mathrm{H}^{\cdots} \mathrm{Cl}$ & 0.0100 & 0.0267 & 0.0065 & -0.0063 & 0.9692 & 0.1967 \\
\hline 23 & $(\mathrm{C})-\mathrm{H}^{\cdots} \mathrm{Cl}$ & 0.0168 & 0.0388 & 0.0104 & -0.0112 & 1.0769 & 0.2251 \\
\hline 23 & (C) $-\mathrm{Cl} \cdots \mathrm{Cs}$ & 0.0070 & 0.0223 & 0.0048 & -0.0040 & 0.8333 & 0.1439 \\
\hline 23 & (C) $-\mathrm{Cl} \cdots \mathrm{Cs}$ & 0.0067 & 0.0215 & 0.0046 & -0.0038 & 0.8261 & 0.1423 \\
\hline 23 & (C) $-\mathrm{Cl} \cdots \mathrm{Cs}$ & 0.0073 & 0.0236 & 0.0051 & -0.0042 & 0.8235 & 0.1439 \\
\hline 23 & $(\mathrm{C})-\mathrm{Cl}^{\cdots} \mathrm{Cs}$ & 0.0071 & 0.0229 & 0.0049 & -0.0041 & 0.8367 & 0.1436 \\
\hline
\end{tabular}


Table S4 Decomposition of the solute-solvent interaction energy (in $\mathrm{kcal} \mathrm{mol}^{-1}$ ) based on SAPT computations.

\begin{tabular}{cccccc}
\hline Model & E_tot & E_elst & E_exch & E_disp & E_ind \\
\hline 01 & -7.79 & -6.62 & 10.42 & -9.63 & -1.96 \\
02 & -15.54 & -11.95 & 20.51 & -20.19 & -3.91 \\
03 & -22.63 & -17.60 & 29.53 & -28.71 & -5.86 \\
10 & -8.61 & -5.94 & 9.35 & -9.87 & -2.14 \\
11 & -17.02 & -12.02 & 20.70 & -21.50 & -4.19 \\
12 & -24.38 & -18.25 & 30.34 & -30.26 & -6.21 \\
13 & -31.80 & -23.23 & 40.10 & -40.76 & -7.91 \\
20 & -14.05 & -9.54 & 18.77 & -19.66 & -3.61 \\
21 & -22.44 & -15.31 & 25.72 & -27.12 & -5.73 \\
22 & -29.19 & -20.22 & 33.49 & -35.28 & -7.19 \\
23 & -34.76 & -23.86 & 39.01 & -41.58 & -8.34 \\
\hline
\end{tabular}


Table S5 Calculated interaction energy (in kcal mol${ }^{-1}$ ) between all fragments based on supermolecule approach.

\begin{tabular}{cccc}
\hline 00 & 01 & 02 & 03 \\
-198.42 & -204.39 & -211.25 & -217.86 \\
\hline 10 & 11 & 12 & 13 \\
-207.56 & -213.94 & -220.61 & -227.27 \\
\hline 20 & 21 & 22 & 23 \\
-216.13 & -221.99 & -227.97 & -235.05 \\
\hline
\end{tabular}




\section{Driving Forces}

To verify the reliability and accuracy of the theoretical methods and basis sets employed to describe the $\mathrm{Cl}^{-} \cdots \mathrm{Cs}^{+}$interactions, the PES and SAPT scans were performed for $\mathrm{Cs}^{+}-\mathrm{Cl}^{-}$ion pair at different levels of theory, as illustrated in Figure S6. For the PES scans (Figure S6 a,c, and e), the potential energy curve yielded by the $\omega \mathrm{B} 97 \mathrm{X}-\mathrm{D} / \mathrm{def} 2-\mathrm{TZVPD}$ level of theory is similar to those produced by the highly accurate $\operatorname{CCSD}(\mathrm{T})$ method (the "gold standard” QM method) with the def2-QZVPD or def2-TZVPD basis sets, and they all give minima at $3.0 \AA$. Moreover, the largest values of $-E$ _tot are also located at $3.0 \AA$ for all the SAPT scans (Figure S6 b,d, and f), consistent with the results obtained from the PES scans. In addition, all energy terms curves calculated at the SAPT0/def2-TZVPD level are close to those computed by the SAPT2+(3) $\delta \mathrm{MP} 2$ method (the "gold standard" SAPT method) with the def2-QZVPD or def2-TZVPD basis sets. Based on these observations, it is suggested that $\omega$ B97X-D/def2-TZVPD and SAPT0/def2-TZVPD can accurately describe the $\mathrm{Cl}^{-\cdots} \mathrm{Cs}^{+}$interactions in the PES and SAPT scans respectively. Therefore, they were used to perform PES and SAPT scans for CP complexes respectively due to their relative low computational cost compared to the "gold standard" methods for these large systems and good accuracy. In addition, it is worth noting that the E_tot comes almost entirely from the contribution of the electrostatic after the distance of $4.0 \AA$, and it can get up to $-41.8 \mathrm{kcal} \mathrm{mol}^{-1}$ even at the $\mathrm{Cl}^{-} \cdots \mathrm{Cs}^{+}$distance of $8.0 \AA$. 
(a)

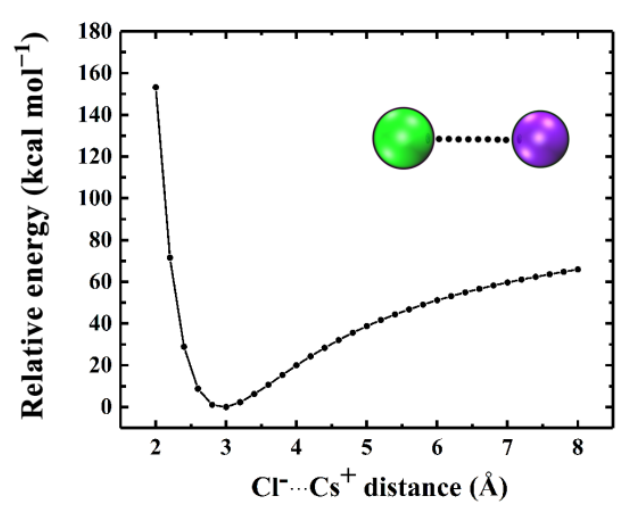

(c)

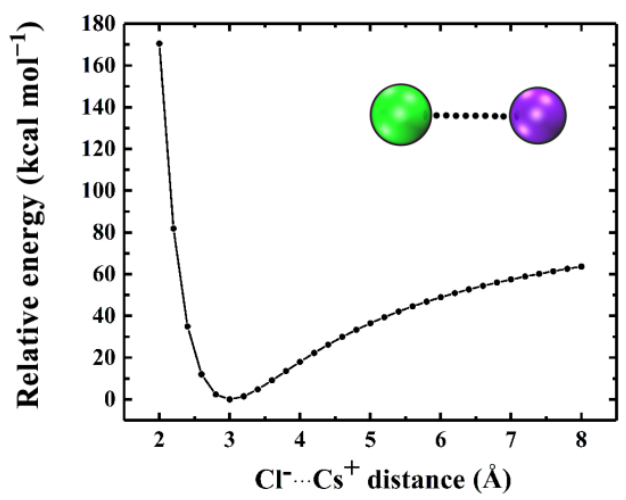

(e)

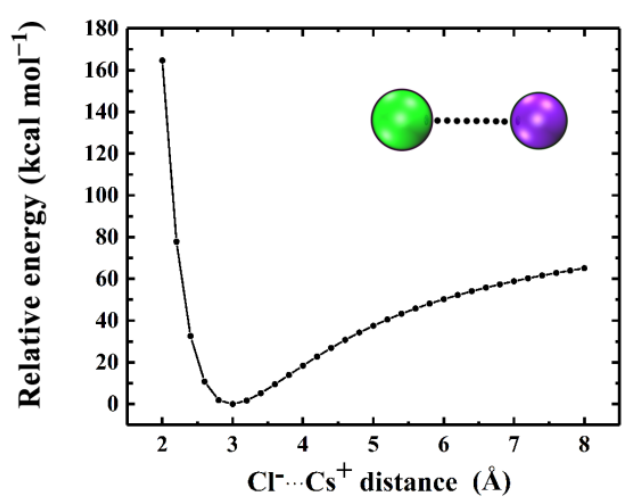

(b)

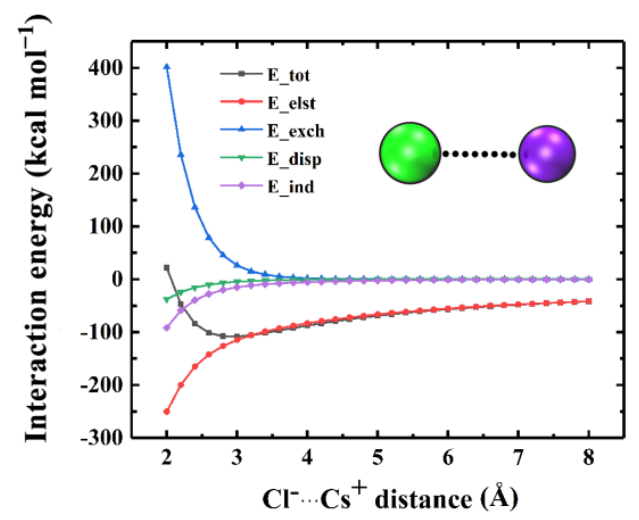

(d)

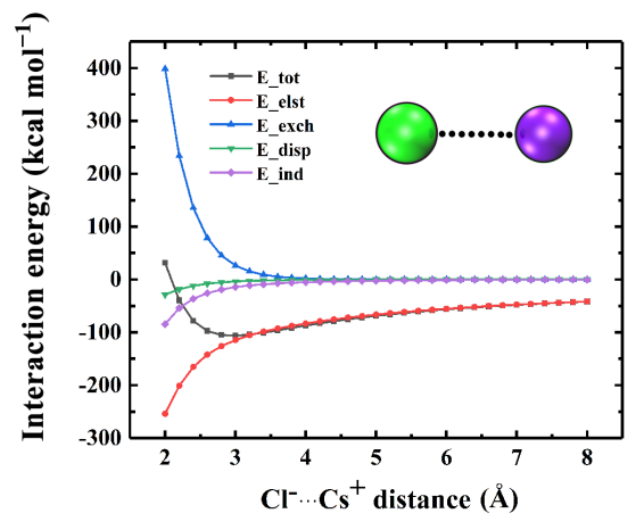

(f)



Figure S6. (a) PES scan for the $\mathrm{Cs}^{+}$: $\mathrm{Cl}^{-}$ion pair at the CCSD(T)/def2-QZVPD level.

(b) SAPT scan for the $\mathrm{Cl}^{-} \cdots \mathrm{Cs}^{+}$interactions at the SAPT2+(3) $\delta \mathrm{MP} 2 /$ def2-QZVPD level.

(c) PES scan for the $\mathrm{Cs}^{+}: \mathrm{Cl}^{-}$ion pair at the CCSD(T)/def2-TZVPD level.

(d) SAPT scan for the $\mathrm{Cl}^{-} \cdots \mathrm{Cs}^{+}$interactions at the SAPT2+(3) $\delta \mathrm{MP} 2 /$ def2-TZVPD level.

(e) PES scan for the $\mathrm{Cs}^{+}$: $\mathrm{Cl}^{-}$ion pair at the $\omega \mathrm{B} 97 \mathrm{X}-\mathrm{D} / \mathrm{def} 2-\mathrm{TZVPD}$ level.

(f) SAPT scan for the $\mathrm{Cl}^{-} \cdots \mathrm{Cs}^{+}$interactions at the SAPT0/def2-TZVPD level. 
The difference between the energy terms for the $\mathrm{Cs}^{+} \cdots \mathrm{CP}: \mathrm{Cl}^{-}$interactions and that for the $\mathrm{Cs}^{+} \cdots \mathrm{CP}$ interactions at corresponding $\mathrm{Cl}^{-} / \mathrm{X} \cdots \mathrm{Cs}^{+}$distance in SAPT scans was calculated and plotted in Figure S7. It is worth noting that although the energy terms for the $\mathrm{Cs}^{+} \cdots \mathrm{Cl}^{-}$interactions cannot be obtained by simply subtracting the energy terms for the $\mathrm{Cs}^{+} \cdots \mathrm{CP}$ interactions from that for the $\mathrm{Cs}^{+} \cdots \mathrm{CP}: \mathrm{Cl}^{-}$interactions due to the polarization and many-body effects in this system, it can still provide qualitative information about the $\mathrm{Cs}^{+} \cdots \mathrm{Cl}^{-}$interactions. It is apparent that the $-E \_$elst for the $\mathrm{Cs}^{+} \cdots \mathrm{CP}: \mathrm{Cl}^{-}$interactions is significantly greater than that for the $\mathrm{Cs}^{+} \cdots \mathrm{CP}$ interactions during the whole scans, while the difference between the other energy terms for them is very small after the distance of $4.0 \AA$. Obviously, this indicates that the $\mathrm{Cs}^{+} \cdots \mathrm{Cl}^{-}$interactions come from the strong electrostatic component. Furthermore, the $-\Delta E \_$tot and the $-E \_$tot for the $\mathrm{Cs}^{+}{ }^{+} \cdot \mathrm{CP}$ interactions are about the same at short distances, and the former is remarkably greater than the latter with increasing distance.

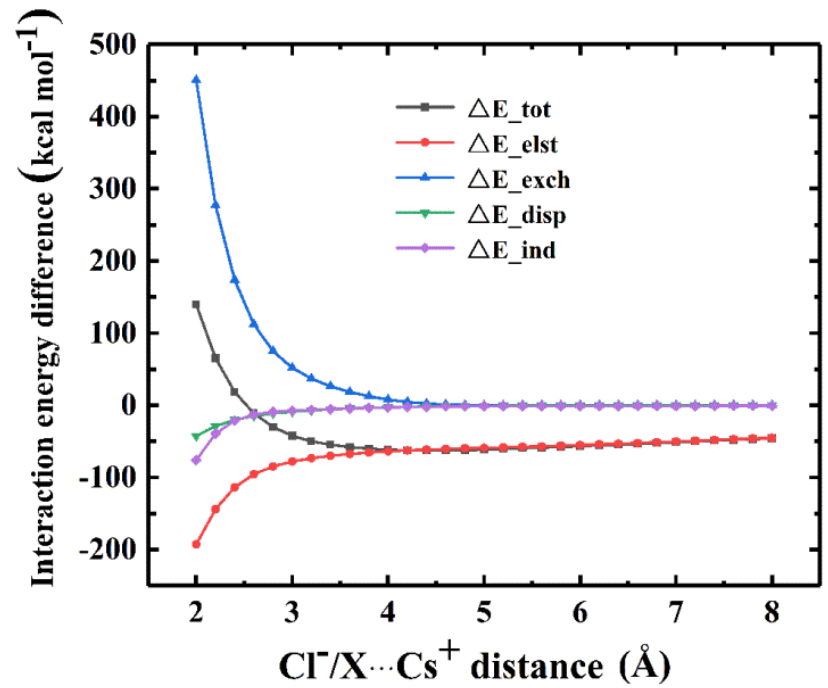

Figure S7. The energy difference between the $\mathrm{Cs}^{+} \cdots \mathrm{CP}: \mathrm{Cl}^{-}$interactions and the $\mathrm{Cs}^{+} \cdots \mathrm{CP}$ interactions at corresponding $\mathrm{Cl}^{-} / \mathrm{X} \cdots \mathrm{Cs}^{+}$distance in SAPT scans. 


\section{Charge-Transfer}

The top five complex orbitals that have the largest values of $d$ or $b$ for fragment pairs were intensively studied, and their $d, b$ and $r$ terms were decomposed to the contributions of pairs of fragment orbitals respectively, as shown in Table S7 and Table S8. In addition, isosurfaces of corresponding fragment orbitals are shown in Figure S8 and Figure S9.

Table S6 CDA results for fragment pairs in $\mathrm{Cs}^{+}: \mathrm{CP}: \mathrm{Cl}^{-}$complex. $(d, b$, and $d-b$ in $e)$

\begin{tabular}{ccccc}
\hline Fragment pair & $d$ & $b$ & $d-b$ & $r$ \\
\hline $\mathrm{CP}^{-C l}{ }^{-}$ & 0.0076 & 0.3348 & -0.3272 & -0.3717 \\
$\mathrm{CP}^{-} \mathrm{Cs}^{+}$ & 0.1016 & 0.0387 & 0.0629 & -0.1738 \\
$\mathrm{Cl}^{-}-\mathrm{Cs}^{+}$ & 0.0139 & 0.0000 & 0.0139 & -0.0015 \\
\hline
\end{tabular}


Table S7 CDA results for the top five complex orbitals that have the largest values of $d$ or $b$ for fragment pair $\mathrm{CP}_{-} \mathrm{Cl}^{-}$and the decomposition of their $d, b$ and $r$ terms into the fragment orbitals pair contributions ${ }^{a}$

\begin{tabular}{|c|c|c|c|c|c|c|}
\hline \multicolumn{2}{|c|}{$\begin{array}{c}\text { Complex orbital } \\
\text { (Occupation number) }\end{array}$} & $d$ & $b$ & \multicolumn{2}{|c|}{$d-b$} & $r$ \\
\hline \multicolumn{2}{|c|}{$51(2.0000)$} & -0.0003 & 0.0333 & \multicolumn{2}{|c|}{-0.0336} & 0.0282 \\
\hline \multicolumn{2}{|c|}{$119(2.0000)$} & 0.0007 & 0.0366 & \multicolumn{2}{|c|}{-0.0359} & -0.0070 \\
\hline \multicolumn{2}{|c|}{$120(2.0000)$} & 0.0099 & 0.1037 & \multicolumn{2}{|c|}{-0.0938} & -0.2157 \\
\hline \multicolumn{2}{|c|}{$121(2.0000)$} & 0.0099 & 0.1036 & \multicolumn{2}{|c|}{-0.0938} & -0.2159 \\
\hline \multicolumn{2}{|c|}{$124(2.0000)$} & 0.0049 & 0.0424 & \multicolumn{2}{|c|}{-0.0376} & -0.1459 \\
\hline $\begin{array}{c}\text { Complex } \\
\text { orbital }\end{array}$ & $\begin{array}{c}\text { CP orbital } \\
\text { (Occupation } \\
\text { number) }\end{array}$ & $\begin{array}{c}\mathrm{Cl}^{-} \text {orbital } \\
\text { (Occupation } \\
\text { number) }\end{array}$ & $d$ & $b$ & $d-b$ & $r$ \\
\hline 51 & $117(0.0000)$ & $6(2.0000)$ & 0.0000 & 0.0313 & -0.0313 & 0.0000 \\
\hline 119 & $117(0.0000)$ & $8(2.0000)$ & 0.0000 & 0.0083 & -0.0083 & 0.0000 \\
\hline 120 & $119(0.0000)$ & $9(2.0000)$ & 0.0000 & 0.0275 & -0.0275 & 0.0000 \\
\hline 121 & $120(0.0000)$ & $7(2.0000)$ & 0.0000 & 0.0445 & -0.0445 & 0.0000 \\
\hline 124 & $117(0.0000)$ & $8(2.0000)$ & 0.0000 & 0.0098 & -0.0098 & 0.0000 \\
\hline
\end{tabular}

${ }^{a}$ For clarity, only the fragment orbitals pair that has the largest contribution to the $d$ or $b$ terms of the corresponding complex orbital is listed.

Table S8 CDA results for the top five complex orbitals that have the largest values of $d$ or $b$ for fragment pair CP-Cs ${ }^{+}$and the decomposition of their $d, b$ and $r$ terms into the fragment orbitals pair contributions ${ }^{a}$

\begin{tabular}{|c|c|c|c|c|c|c|}
\hline \multicolumn{2}{|c|}{$\begin{array}{c}\text { Complex orbital } \\
\text { (Occupation number) }\end{array}$} & $d$ & $b$ & \multicolumn{2}{|c|}{$d-b$} & $r$ \\
\hline \multicolumn{2}{|c|}{$38(2.0000)$} & 0.0002 & 0.0130 & \multicolumn{2}{|c|}{-0.0128} & 0.0109 \\
\hline \multicolumn{2}{|c|}{$74(2.0000)$} & -0.0010 & 0.0213 & \multicolumn{2}{|c|}{-0.0223} & 0.0818 \\
\hline \multicolumn{2}{|c|}{$75(2.0000)$} & -0.0010 & 0.0213 & \multicolumn{2}{|c|}{-0.0223} & 0.0817 \\
\hline \multicolumn{2}{|c|}{$124(2.0000)$} & 0.0174 & 0.0005 & \multicolumn{2}{|c|}{0.0169} & -0.0129 \\
\hline \multicolumn{2}{|c|}{$126(2.0000)$} & 0.0177 & 0.0000 & \multicolumn{2}{|c|}{0.0177} & 0.0000 \\
\hline $\begin{array}{c}\text { Complex } \\
\text { orbital }\end{array}$ & $\begin{array}{c}\text { CP orbital } \\
\text { (Occupation } \\
\text { number) }\end{array}$ & $\begin{array}{l}\mathrm{Cs}^{+} \text {orbital } \\
\text { (Occupation } \\
\text { number) }\end{array}$ & $d$ & $b$ & $d-b$ & $r$ \\
\hline 38 & $132(0.0000)$ & $1(2.0000)$ & 0.0000 & 0.0040 & -0.0040 & 0.0000 \\
\hline 74 & $155(0.0000)$ & $4(2.0000)$ & 0.0000 & 0.0016 & -0.0016 & 0.0000 \\
\hline 75 & $154(0.0000)$ & $2(2.0000)$ & 0.0000 & 0.0028 & -0.0028 & 0.0000 \\
\hline 124 & $109(2.0000)$ & $9(0.0000)$ & 0.0075 & 0.0000 & 0.0075 & 0.0000 \\
\hline 126 & $113(2.0000)$ & $10(0.0000)$ & 0.0072 & 0.0000 & 0.0072 & 0.0000 \\
\hline
\end{tabular}

${ }^{a}$ For clarity, only the fragment orbitals pair that has the largest contribution to the $d$ or $b$ terms of the corresponding complex orbital is listed. 


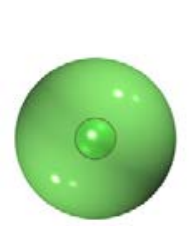

6

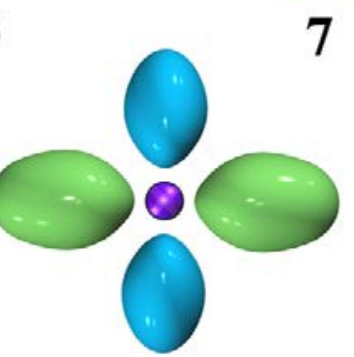

9



7

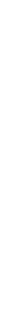

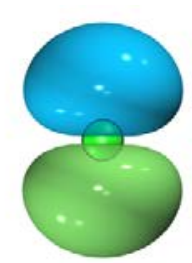

8

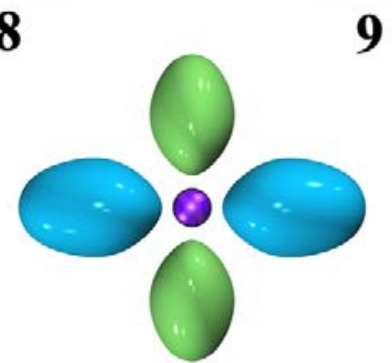

10

Figure S8. Isosurfaces (isovalue $=0.04$ a.u.) of relevant fragment orbitals of $\mathrm{Cl}^{-}$and $\mathrm{Cs}^{+}$. Color code: $\mathrm{Cl}$, green; $\mathrm{Cs}$, violet.

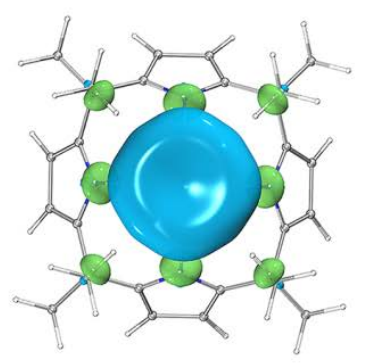

117

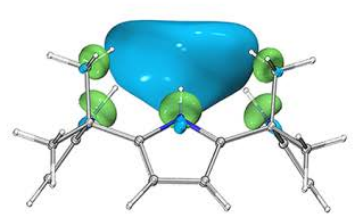

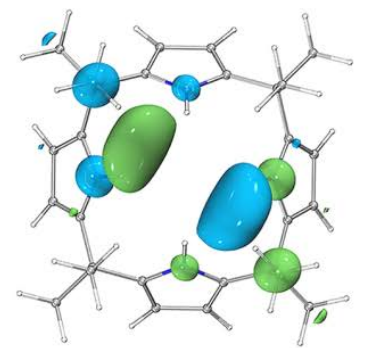

119





9



120



109

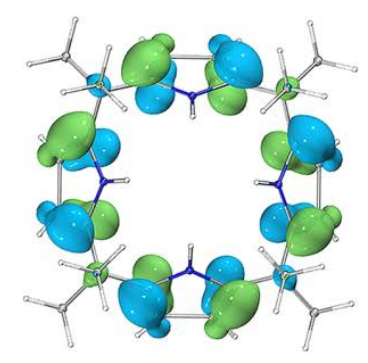

113

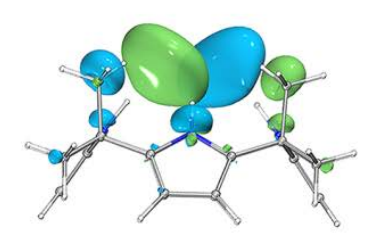




\section{References}

(1) Gale, P. A.; Sessler, J. L.; Kral, V.; Lynch, V. Calix[4]pyrroles: old yet new anion-binding agents. J. Am. Chem. Soc. 1996, 118 (21), 5140-5141.

(2) Martinez, L.; Andrade, R.; Birgin, E. G.; Martinez, J. M. PACKMOL: a package for building initial configurations for molecular dynamics simulations. J. Comput. Chem. 2009, 30 (13), 2157-2164.

(3) Helgaker, T.; Uggerud, E.; Jensen, H. J. A. Integration of the classical equations of motion on $a b$ initio molecular potential energy surfaces using gradients and Hessians: application to translational energy release upon fragmentation. Chem. Phys. Lett. 1990, 173 (2-3), 145-150.

(4) Becke, A. D. Density-functional exchange-energy approximation with correct asymptotic behavior. Phys. Rev. A 1988, 38 (6), 3098-3100.

(5) Lee, C.; Yang, W.; Parr, R. G. Development of the Colle-Salvetti correlation-energy formula into a functional of the electron density. Phys. Rev. B 1988, 37 (2), 785-789.

(6) Grimme, S.; Antony, J.; Ehrlich, S.; Krieg, H. A consistent and accurate $a b$ initio parametrization of density functional dispersion correction (DFT-D) for the 94 elements H-Pu. J. Chem. Phys. 2010, 132 (15), 154104.

(7) Grimme, S.; Ehrlich, S.; Goerigk, L. Effect of the damping function in dispersion corrected density functional theory. J. Comput. Chem. 2011, 32 (7), 1456-1465.

(8) Kruse, H.; Grimme, S. A geometrical correction for the inter- and intra-molecular basis set superposition error in Hartree-Fock and density functional theory calculations for large systems. J. Chem. Phys. 2012, 136 (15), 154101.

(9) Weigend, F.; Ahlrichs, R. Balanced basis sets of split valence, triple zeta valence and quadruple zeta valence quality for $\mathrm{H}$ to $\mathrm{Rn}$ : design and assessment of accuracy. Phys. Chem. Chem. Phys. 2005, 7 (18), 3297-3305.

(10) Baerends, E. J.; Ellis, D. E.; Ros, P. Self-consistent molecular Hartree-Fock-Slater calculations I. The computational procedure. Chem. Phys. 1973, 2 (1), 41-51.

(11) Eichkorn, K.; Weigend, F.; Treutler, O.; Ahlrichs, R. Auxiliary basis sets for main 
row atoms and transition metals and their use to approximate Coulomb potentials. Theor. Chem. Acc. 1997, 97 (1-4), 119-124.

(12) Weigend, F. Accurate Coulomb-fitting basis sets for H to Rn. Phys. Chem. Chem. Phys. 2006, 8 (9), 1057-1065.

(13) Berendsen, H. J. C.; Postma, J. P. M.; van Gunsteren, W. F.; DiNola, A.; Haak, J. R. Molecular dynamics with coupling to an external bath. J. Chem. Phys. 1984, 81 (8), 3684-3690.

(14) Swope, W. C.; Andersen, H. C.; Berens, P. H.; Wilson, K. R. A computer simulation method for the calculation of equilibrium constants for the formation of physical clusters of molecules: application to small water clusters. J. Chem. Phys. 1982, 76 (1), 637-649.

(15) (a) Neese, F. The ORCA program system. WIREs. Comput. Mol. Sci. 2012, 2 (1), 73-78. (b) Neese, F. Software update: the ORCA program system, version 4.0. WIREs. Comput. Mol. Sci. 2018, 8 (1), e1327.

(16) Humphrey, W.; Dalke, A.; Schulten, K. VMD: visual molecular dynamics. J. Mol. Graphics 1996, 14 (1), 33-38.

(17) (a) Chai, J. D.; Head-Gordon, M. Systematic optimization of long-range corrected hybrid density functionals. J. Chem. Phys. 2008, 128 (8), 084106. (b) Chai, J. D.; Head-Gordon, M. Long-range corrected hybrid density functionals with damped atom-atom dispersion corrections. Phys. Chem. Chem. Phys. 2008, 10 (44), 6615-6620.

(18) Rappoport, D.; Furche, F. Property-optimized Gaussian basis sets for molecular response calculations. J. Chem. Phys. 2010, 133 (13), 134105.

(19) Boys, S. F.; Bernardi, F. The calculation of small molecular interactions by the differences of separate total energies. Some procedures with reduced errors. Mol. Phys. 1970, 19 (4), 553-566.

(20) Pople, J. A.; Head-Gordon, M.; Raghavachari, K. Quadratic configuration interaction. A general technique for determining electron correlation energies. $J$. Chem. Phys. 1987, 87 (10), 5968-5975.

(21) Frisch, M. J.; Trucks, G. W.; Schlegel, H. B.; Scuseria, G. E.; Robb, M. A.; S27 
Cheeseman, J. R.; Scalmani, G.; Barone, V.; Mennucci, B.; Petersson, G. A.; Nakatsuji, H.; Caricato, M.; Li, X.; Hratchian, H. P.; Izmaylov, A. F.; Bloino, J.; Zheng, G.; Sonnenberg, J. L.; Hada, M.; Ehara, M.; Toyota, K.; Fukuda, R.; Hasegawa, J.; Ishida, M.; Nakajima, T.; Honda, Y.; Kitao, O.; Nakai, H.; Vreven, T.; Montgomery Jr., J. A.; Peralta, J. E.; Ogliaro, F.; Bearpark, M.; Heyd, J. J.; Brothers, E.; Kudin, K. N.; Staroverov, V. N.; Keith, T.; Kobayashi, R.; Normand, J.; Raghavachari, K.; Rendell, A.; Burant, J. C.; Iyengar, S. S.; Tomasi, J.; Cossi, M.; Rega, N.; Millam, J. M.; Klene, M.; Knox, J. E.; Cross, J. B.; Bakken, V.; Adamo, C.; Jaramillo, J.; Gomperts, R.; Stratmann, R. E.; Yazyev, O.; Austin, A. J.; Cammi, R.; Pomelli, C.; Ochterski, J. W.; Martin, R. L.; Morokuma, K.; Zakrzewski, V. G.; Voth, G. A.; Salvador, P.; Dannenberg, J. J.; Dapprich, S.; Daniels, A. D.; Farkas, O.; Foresman, J. B.; Ortiz, J. V.; Cioslowski, J.; Fox, D. J. Gaussian 09, Revision D.01, Gaussian, Inc., Wallingford CT, 2009.

(22) Dennington, R.; Keith, T.; Millam, J. GaussView, Version 5, Semichem Inc., Shawnee Mission, KS, 2009.

(23) Jeziorski, B.; Moszynski, R.; Szalewicz, K. Perturbation theory approach to intermolecular potential energy surfaces of van der Waals complexes. Chem. Rev. 1994, 94 (7), 1887-1930.

(24) Szalewicz, K. Symmetry-adapted perturbation theory of intermolecular forces. WIREs Comput. Mol. Sci. 2012, 2 (2), 254-272.

(25) Hohenstein, E. G.; Sherrill, C. D. Wavefunction methods for noncovalent interactions. WIREs Comput. Mol. Sci. 2012, 2 (2), 304-326.

(26) Parker, T. M.; Burns, L. A.; Parrish, R. M.; Ryno, A. G.; Sherrill, C. D. Levels of symmetry adapted perturbation theory (SAPT). I. Efficiency and performance for interaction energies. J. Chem. Phys. 2014, 140 (9), 094106.

(27) Patkowski, K. Recent developments in symmetry-adapted perturbation theory. WIREs Comput. Mol. Sci. 2020, 10 (3), e1452.

(28) Hohenstein, E. G.; Sherrill, C. D. Density fitting and Cholesky decomposition approximations in symmetry-adapted perturbation theory: implementation and application to probe the nature of $\pi$ - $\pi$ interactions in linear acenes. J. Chem. Phys. 
2010, 132 (18), 184111.

(29) (a) Turney, J. M.; Simmonett, A. C.; Parrish, R. M.; Hohenstein, E. G.; Evangelista, F. A.; Fermann, J. T.; Mintz, B. J.; Burns, L. A.; Wilke, J. J.; Abrams, M. L.; Russ, N. J.; Leininger, M. L.; Janssen, C. L.; Seidl, E. T.; Allen, W. D.; Schaefer, H. F.; King, R. A.; Valeev, E. F.; Sherrill, C. D.; Crawford, T. D. PSI4: an open-source $a b$ initio electronic structure program. WIREs Comput. Mol. Sci. 2012, 2 (4), 556-565. (b) Parrish, R. M.; Burns, L. A.; Smith, D. G. A.; Simmonett, A. C.; DePrince, III, A. E.; Hohenstein, E. G.; Bozkaya, U.; Sokolov, A. Yu.; Di Remigio, R.; Richard, R. M.; Gonthier, J. F.; James, A. M.; McAlexander, H. R.; Kumar, A.; Saitow, M.; Wang, X.; Pritchard, B. P.; Verma, P.; Schaefer, III, H. F.; Patkowski, K.; King, R. A.; Valeev, E. F.; Evangelista, F. A.; Turney, J. M.; Crawford, T. D.; Sherrill, C. D. PSI4 1.1: an open-source electronic structure program emphasizing automation, advanced libraries, and interoperability. J. Chem. Theory Comput. 2017, 13 (7), 3185-3197.

(30) Bader, R. F. W. Atoms in molecules. Acc. Chem. Res. 1985, 18 (1), 9-15.

(31) Bader, R. F. W. A quantum theory of molecular structure and its applications. Chem. Rev. 1991, 91 (5), 893-928.

(32) Lu, T.; Chen, F. Multiwfn: a multifunctional wavefunction analyzer. J. Comput. Chem. 2012, 33 (5), 580-592.

(33) Johnson, E. R.; Keinan, S.; Mori-Sanchez, P.; Contreras-Garcia, J.; Cohen, A. J.; Yang, W. Revealing noncovalent interactions. J. Am. Chem. Soc. 2010, 132 (18), 6498-6506.

(34) Dapprich, S.; Frenking, G. Investigation of donor-acceptor interactions: a charge decomposition analysis using fragment molecular orbitals. J. Phys. Chem. 1995, 99 (23), 9352-9362.

(35) Gorelsky, S. I.; Solomon, E. I. Extended charge decomposition analysis and its application for the investigation of electronic relaxation. Theor. Chem. Account. 2008, 119 (1-3), 57-65.

(36) Xiao, M.; Lu, T. Generalized charge decomposition analysis (GCDA) method. J. Adv. Phys. Chem. 2015, 4 (4), 111-124. 


\section{Coordinates}

Atom coordinates for all structures including absolute energies (in Hartrees) from QM geometry optimization at the $\omega \mathrm{B} 97 \mathrm{X}-\mathrm{D} / \mathrm{def} 2-\mathrm{SVP}$ level.

00

$E=-1786.8321417$

$\mathrm{N}$

$\mathrm{N}$

$\mathrm{N}$

$\mathrm{N}$

C

C

C

C

C

C

C

C

C

C

C

C

C

C

C

C

C

C

C

C

C

C

C

C

C

C

C

C

$\mathrm{H}$

$\mathrm{H}$

$\mathrm{H}$

$\mathrm{H}$

$\mathrm{H}$

$\mathrm{H}$

$\mathrm{H}$

$\mathrm{H}$

$\mathrm{H}$

$\mathrm{H}$

\begin{tabular}{rrr}
1.91271000 & 1.51841800 & -0.66091500 \\
1.51851400 & -1.91220200 & -0.66060100 \\
-1.91238700 & -1.51805100 & -0.66081300 \\
-1.51837000 & 1.91253800 & -0.66091400 \\
1.55838100 & 2.68006200 & -0.01884900 \\
2.39567100 & 2.81150400 & 1.07252800 \\
3.28122800 & 1.69558600 & 1.07275800 \\
2.96342900 & 0.90961200 & -0.01847300 \\
3.55729200 & -0.40868200 & -0.48817600 \\
2.68030800 & -1.55825400 & -0.01854700 \\
2.81150200 & -2.39570300 & 1.07277000 \\
1.69543500 & -3.28110800 & 1.07279000 \\
0.90961500 & -2.96296300 & -0.01843600 \\
-0.40851600 & -3.55664300 & -0.48871000 \\
-1.55838400 & -2.68004600 & -0.01910200 \\
-2.39643800 & -2.81210900 & 1.07164300 \\
-3.28199400 & -1.69613300 & 1.07191000 \\
-2.96346600 & -0.90959200 & -0.01868400 \\
-3.55710500 & 0.40877100 & -0.48836800 \\
-2.68004400 & 1.55833300 & -0.01872800 \\
-2.81147800 & 2.39596200 & 1.07243500 \\
-1.69542600 & 3.28140000 & 1.07267000 \\
-0.90956000 & 2.96332400 & -0.01854900 \\
0.40872600 & 3.55690500 & -0.48859300 \\
4.95367400 & -0.56895200 & 0.12647700 \\
3.69102400 & -0.42393600 & -2.02288900 \\
-0.42316000 & -3.68989400 & -2.02349900 \\
-0.56885300 & -4.95316700 & 0.12555000 \\
-4.95347800 & 0.56917400 & 0.12623900 \\
-3.69071000 & 0.42396900 & -2.02309200 \\
0.42381400 & 3.69014700 & -2.02331200 \\
0.56918100 & 4.95342500 & 0.12562300 \\
1.42413400 & 1.13091600 & -1.47644200 \\
1.13145000 & -1.42392500 & -1.47641900 \\
-1.42387900 & -1.13050600 & -1.47628400 \\
-1.13097300 & 1.42408100 & -1.47652600 \\
2.39710000 & 3.63607400 & 1.78102500 \\
4.08379600 & 1.50985600 & 1.78217600 \\
3.63606200 & -2.39741300 & 1.78128700 \\
1.50959300 & -4.08380000 & 1.78205100 \\
-2.39839200 & -3.63709100 & 1.77966300 \\
-4.08509100 & -1.51079400 & 1.78086200 \\
& $S 30$ & \\
\hline & &
\end{tabular}




$\begin{array}{lrrr}\mathrm{H} & -3.63611400 & 2.39757000 & 1.78082000 \\ \mathrm{H} & -1.50977600 & 4.08426200 & 1.78179200 \\ \mathrm{H} & 4.92284300 & -0.56546100 & 1.22502500 \\ \mathrm{H} & 5.40110300 & -1.52021900 & -0.19518200 \\ \mathrm{H} & 5.60504200 & 0.25618900 & -0.19500200 \\ \mathrm{H} & 2.72516600 & -0.31145100 & -2.53704100 \\ \mathrm{H} & 4.34202400 & 0.39988400 & -2.35082200 \\ \mathrm{H} & 4.13560000 & -1.37496500 & -2.35151900 \\ \mathrm{H} & -1.37378400 & -4.13497200 & -2.35263200 \\ \mathrm{H} & -0.31110400 & -2.72378900 & -2.53732900 \\ \mathrm{H} & 0.40115100 & -4.34033000 & -2.35133700 \\ \mathrm{H} & -0.56515500 & -4.92258100 & 1.22410700 \\ \mathrm{H} & -1.52027700 & -5.40029500 & -0.19602900 \\ \mathrm{H} & 0.25613300 & -5.60455900 & -0.19619700 \\ \mathrm{H} & -4.92270100 & 0.56499200 & 1.22478800 \\ \mathrm{H} & -5.40051800 & 1.52081500 & -0.19484900 \\ \mathrm{H} & -5.60514300 & -0.25551300 & -0.19573100 \\ \mathrm{H} & -2.72466800 & 0.31223700 & -2.53714000 \\ \mathrm{H} & -4.34102100 & -0.40035200 & -2.35108200 \\ \mathrm{H} & -4.13599100 & 1.37464000 & -2.35179400 \\ \mathrm{H} & 0.31237700 & 2.72392700 & -2.53707100 \\ \mathrm{H} & -0.40079800 & 4.34007400 & -2.35138200 \\ \mathrm{H} & 1.37431800 & 4.13570200 & -2.35211300 \\ \mathrm{H} & 0.56495600 & 4.92306600 & 1.22417600 \\ \mathrm{H} & 1.52087200 & 5.40030300 & -0.19549600 \\ \mathrm{H} & -0.25540000 & 5.60510700 & -0.19664300 \\ \mathrm{Cl} & 0.00036500 & -0.00012400 & -2.77808300 \\ \mathrm{Cs} & -0.00029800 & -0.00019000 & 1.63072900\end{array}$


01

$E=-2746.2112369$

$\mathrm{N}$

$\mathrm{N}$

$\mathrm{N}$

$\mathrm{N}$

C

C

C

C

C

C

C

C

C

C

C

C

C

C

C

C

C

C

C

C

C

C

C

C

C

C

C

C

$\mathrm{H}$

$\mathrm{H}$

$\mathrm{H}$

$\mathrm{H}$

$\mathrm{H}$

$\mathrm{H}$

$\mathrm{H}$

$\mathrm{H}$

H

$\mathrm{H}$

$\mathrm{H}$

$\mathrm{H}$

$\mathrm{H}$

$\mathrm{H}$

$\mathrm{H}$

\begin{tabular}{rrr}
0.83986200 & 2.33921700 & -0.70006700 \\
2.39604300 & -0.64239100 & -1.46324200 \\
-0.14789800 & -2.37961100 & 0.10702900 \\
-1.71753000 & 0.60246000 & 0.85245100 \\
0.29939700 & 3.08177100 & 0.32206200 \\
1.34614400 & 3.73111700 & 0.94771800 \\
2.54540800 & 3.36901500 & 0.26881600 \\
2.20216400 & 2.50731700 & -0.75518900 \\
3.07379800 & 1.78658600 & -1.77034100 \\
3.32193000 & 0.36100700 & -1.30552100 \\
4.40475200 & -0.18765000 & -0.64631100 \\
4.11684400 & -1.56324000 & -0.41388200 \\
2.86461300 & -1.82198500 & -0.93646500 \\
2.04731000 & -3.10341800 & -0.94226000 \\
1.03881800 & -3.06619200 & 0.19393600 \\
1.09668400 & -3.61613300 & 1.46004800 \\
-0.09931700 & -3.25123400 & 2.14313200 \\
-0.85893500 & -2.48755000 & 1.27796300 \\
-2.20706800 & -1.81529200 & 1.47691600 \\
-1.99816600 & -0.34542200 & 1.80674900 \\
-1.98953700 & 0.29780200 & 3.02954400 \\
-1.70515500 & 1.67285200 & 2.79183100 \\
-1.54618300 & 1.83796700 & 1.42923100 \\
-1.18884800 & 3.08214100 & 0.63019300 \\
4.41992800 & 2.51497300 & -1.87240100 \\
2.40567200 & 1.79342000 & -3.15852700 \\
1.33372100 & -3.28233300 & -2.29567700 \\
2.99272600 & -4.29234300 & -0.72696700 \\
-2.92856400 & -2.48730900 & 2.65191300 \\
-3.07348200 & -1.97795800 & 0.21576600 \\
-2.00034900 & 3.14990300 & -0.67638100 \\
-1.52145100 & 4.32072700 & 1.47231600 \\
0.30431700 & 1.71160000 & -1.30878700 \\
1.46884200 & -0.51988200 & -1.88198900 \\
-0.44359100 & -1.82925800 & -0.70516700 \\
-1.62464300 & 0.41063700 & -0.14935600 \\
1.26192500 & 4.42136800 & 1.78337800 \\
3.54626500 & 3.73075800 & 0.49095700 \\
5.32345100 & 0.33141000 & -0.38473900 \\
4.77448600 & -2.28838000 & 0.05882100 \\
1.89591500 & -4.24219200 & 1.84885700 \\
-0.38237100 & -3.54618400 & 3.15053600 \\
-2.19428300 & -0.16081200 & 3.99357800 \\
-1.65297800 & 2.45804700 & 3.54169900 \\
4.94396000 & 2.54578000 & -0.90695500 \\
\hline .07286600 & 2.00458700 & -2.59453600 \\
\hline
\end{tabular}




$\begin{array}{lrrr}\mathrm{H} & 1.43021300 & 1.28557000 & -3.16742800 \\ \mathrm{H} & 2.24577600 & 2.82900800 & -3.49311700 \\ \mathrm{H} & 3.05289000 & 1.28494500 & -3.88825900 \\ \mathrm{H} & 0.76276200 & -4.22250200 & -2.29756600 \\ \mathrm{H} & 0.63237000 & -2.46595800 & -2.52263500 \\ \mathrm{H} & 2.07515500 & -3.32063600 & -3.10722900 \\ \mathrm{H} & 3.53025400 & -4.22134800 & 0.22884000 \\ \mathrm{H} & 2.42410900 & -5.23314200 & -0.72436300 \\ \mathrm{H} & 3.74037200 & -4.33184100 & -1.53176900 \\ \mathrm{H} & -2.35748800 & -2.40857300 & 3.58765000 \\ \mathrm{H} & -3.90724300 & -2.01333900 & 2.81261200 \\ \mathrm{H} & -3.08314900 & -3.55477200 & 2.44009700 \\ \mathrm{H} & -2.60741700 & -1.54046300 & -0.67872600 \\ \mathrm{H} & -3.24111300 & -3.04487500 & 0.00843500 \\ \mathrm{H} & -4.04730600 & -1.48826000 & 0.35344500 \\ \mathrm{H} & -1.80367200 & 2.29616200 & -1.34115600 \\ \mathrm{H} & -3.07681100 & 3.15548400 & -0.45677100 \\ \mathrm{H} & -1.74399200 & 4.06724500 & -1.22705700 \\ \mathrm{H} & -0.97229300 & 4.33242800 & 2.42414000 \\ \mathrm{H} & -1.25930100 & 5.23500400 & 0.92097100 \\ \mathrm{H} & -2.59615400 & 4.34203100 & 1.70233200 \\ \mathrm{C} & -4.36756600 & 0.28054200 & -2.41541400 \\ \mathrm{H} & -4.65728900 & 0.95752800 & -3.22516600 \\ \mathrm{H} & -3.27634200 & 0.17619700 & -2.35316900 \\ \mathrm{Cl} & -5.06060000 & -1.31917800 & -2.75495200 \\ \mathrm{Cl} & -4.96932600 & 0.97351300 & -0.88778700 \\ \mathrm{Cl} & -0.74193000 & -0.10019900 & -2.16108700 \\ \mathrm{Cs} & 1.48278600 & 0.08205200 & 1.68507800\end{array}$


02

$E=-3705.59242$

$\mathrm{N}$

$\mathrm{N}$

$\mathrm{N}$

$\mathrm{N}$

C

C

C

C

C

C

C

C

C

C

C

C

C

C

C

C

C

C

C

C

C

C

C

C

C

C

C

C

$\mathrm{H}$

$\mathrm{H}$

$\mathrm{H}$

$\mathrm{H}$

$\mathrm{H}$

$\mathrm{H}$

$\mathrm{H}$

H

$\mathrm{H}$

$\mathrm{H}$

$\mathrm{H}$

$\mathrm{H}$

$\mathrm{H}$

$\mathrm{H}$

$\mathrm{H}$

$\begin{array}{ccc}-1.56778400 & 2.11028900 & 1.09296000 \\ -2.27270100 & -1.24580500 & 1.49736400 \\ 0.21666700 & -2.03961800 & -0.75857400 \\ 0.90918800 & 1.30769200 & -1.16046900 \\ -1.42131000 & 3.10485600 & 0.15558300 \\ -2.68939400 & 3.55045800 & -0.16229600 \\ -3.61780800 & 2.80373700 & 0.61902000 \\ -2.89468500 & 1.92007100 & 1.39588600 \\ -3.36677600 & 0.86590700 & 2.38246900 \\ -3.40149900 & -0.48670200 & 1.69184200 \\ -4.45362500 & -1.17042200 & 1.11476800 \\ -3.93432800 & -2.37994800 & 0.56936500 \\ -2.57750900 & -2.40607800 & 0.82627600 \\ -1.52395300 & -3.43759500 & 0.46019800 \\ -0.77955300 & -2.98587400 & -0.78623100 \\ -0.95841700 & -3.34505200 & -2.10801700 \\ -0.03085300 & -2.59645500 & -2.88794200 \\ 0.69363400 & -1.79741000 & -2.02477000 \\ 1.78943600 & -0.78323900 & -2.31166000 \\ 1.20518700 & 0.62032500 & -2.31414100 \\ 0.83935800 & 1.43032500 & -3.37095900 \\ 0.32223500 & 2.64159500 & -2.82831800 \\ 0.38395900 & 2.54402200 & -1.45229000 \\ -0.06413300 & 3.52574000 & -0.38147100 \\ -4.78409800 & 1.22176700 & 2.84934200 \\ -2.44227400 & 0.82349000 & 3.61397100 \\ -0.55182500 & -3.64582000 & 1.63595400 \\ -2.21900200 & -4.77278700 & 0.16445800 \\ 2.37997300 & -1.07292500 & -3.69739600 \\ 2.91747500 & -0.89634800 & -1.27220600 \\ 0.96305500 & 3.59937700 & 0.76211000 \\ -0.19022200 & 4.91841500 & -1.01180300 \\ -0.79608800 & 1.56995700 & 1.49173300 \\ -1.32930600 & -0.97031200 & 1.78371900 \\ 0.54623900 & -1.56704600 & 0.08745100 \\ 1.04162100 & 0.94000500 & -0.21462500 \\ -2.92911800 & 4.34955400 & -0.85925700 \\ -4.69780100 & 2.92780600 & 0.62952200 \\ -5.49401100 & -0.85519200 & 1.10824300 \\ -4.50495900 & -3.15969400 & 0.07114600 \\ -1.66018500 & -4.08771100 & -2.47894200 \\ 0.10975600 & -2.66538400 & -3.96361500 \\ -0.96070900 & 1.19843000 & -4.42594800 \\ -5.02642300 & 3.50277000 & -3.39248600 \\ -4.78464200 & 2.20508600 & 3.34057100\end{array}$




$\begin{array}{lrrr}\mathrm{H} & -1.40027100 & 0.57576100 & 3.36332200 \\ \mathrm{H} & -2.43895900 & 1.80300900 & 4.11414000 \\ \mathrm{H} & -2.80125000 & 0.06703900 & 4.32726400 \\ \mathrm{H} & 0.20354900 & -4.39949200 & 1.37452100 \\ \mathrm{H} & -0.01796300 & -2.72472600 & 1.91246300 \\ \mathrm{H} & -1.10569000 & -3.98784100 & 2.52278700 \\ \mathrm{H} & -2.94086100 & -4.68852600 & -0.65983700 \\ \mathrm{H} & -1.47463900 & -5.53174400 & -0.11463000 \\ \mathrm{H} & -2.76346200 & -5.12044800 & 1.05390700 \\ \mathrm{H} & 1.61975900 & -1.01490100 & -4.48888300 \\ \mathrm{H} & 3.16785600 & -0.34307800 & -3.93076900 \\ \mathrm{H} & 2.81490500 & -2.08210000 & -3.71856400 \\ \mathrm{H} & 2.56339500 & -0.69307400 & -0.25111900 \\ \mathrm{H} & 3.34416700 & -1.90870700 & -1.27831200 \\ \mathrm{H} & 3.71095000 & -0.16986000 & -1.49550700 \\ \mathrm{H} & 1.09008800 & 2.63875600 & 1.28197300 \\ \mathrm{H} & 1.94606100 & 3.89861800 & 0.37308100 \\ \mathrm{H} & 0.64067000 & 4.33603500 & 1.51224200 \\ \mathrm{H} & -0.91809300 & 4.93319600 & -1.83496100 \\ \mathrm{H} & -0.51971800 & 5.64637400 & -0.25705800 \\ \mathrm{H} & 0.78135500 & 5.23968500 & -1.41296900 \\ \mathrm{C} & 3.39347000 & -2.69422400 & 1.91268300 \\ \mathrm{H} & 3.42708900 & -3.14891600 & 2.90756700 \\ \mathrm{H} & 2.62143000 & -1.91562000 & 1.85844900 \\ \mathrm{Cl} & 3.01172200 & -3.97353500 & 0.73797300 \\ \mathrm{Cl} & 4.97765300 & -1.94366500 & 1.60278500 \\ \mathrm{C} & 4.00684600 & 1.68619100 & 1.14961000 \\ \mathrm{H} & 3.00330900 & 1.24596600 & 1.17605900 \\ \mathrm{H} & 4.76630500 & 0.91191600 & 1.29473800 \\ \mathrm{Cl} & 4.12823400 & 2.85565800 & 2.47942200 \\ \mathrm{Cl} & 4.27230700 & 2.43327000 & -0.44498200 \\ \mathrm{Cl} & 0.79275000 & -0.08889600 & 1.78817700 \\ \mathrm{Cs} & -2.18501900 & 0.14298800 & -1.56408400\end{array}$


03

$E=-4664.9715293$

\begin{tabular}{|c|c|c|c|}
\hline $\mathrm{N}$ & 1.82186900 & 0.97320200 & -1.96754300 \\
\hline $\mathrm{N}$ & 1.92008300 & -1.86412500 & 0.01463700 \\
\hline $\mathrm{N}$ & -0.31928500 & -0.42339500 & 2.20537700 \\
\hline $\mathrm{N}$ & -0.42085000 & 2.40426700 & 0.21889600 \\
\hline C & 1.97156100 & 2.33918600 & -1.94238300 \\
\hline C & 3.32758600 & 2.59686800 & -1.99272700 \\
\hline $\mathrm{C}$ & 4.00312100 & 1.34415800 & -2.06137900 \\
\hline C & 3.04409800 & 0.35035300 & -2.05108400 \\
\hline C & 3.19340400 & -1.16170100 & -2.07179200 \\
\hline C & 3.11301300 & -1.69422600 & -0.65079200 \\
\hline C & 4.11866000 & -2.04234500 & 0.22814300 \\
\hline $\mathrm{C}$ & 3.50625100 & -2.43826000 & 1.45195100 \\
\hline $\mathrm{C}$ & 2.14003600 & -2.32340200 & 1.29380700 \\
\hline $\mathrm{C}$ & 1.01177000 & -2.58868900 & 2.27632300 \\
\hline $\mathrm{C}$ & 0.52975700 & -1.27544500 & 2.87040800 \\
\hline $\mathrm{C}$ & 0.84440300 & -0.67299300 & 4.07297900 \\
\hline $\mathrm{C}$ & 0.15086200 & 0.57002900 & 4.12790400 \\
\hline $\mathrm{C}$ & -0.57191900 & 0.69839300 & 2.95786900 \\
\hline $\mathrm{C}$ & -1.45853500 & 1.83369700 & 2.47176700 \\
\hline $\mathrm{C}$ & -0.66688900 & 2.73007200 & 1.53235400 \\
\hline $\mathrm{C}$ & -0.03518200 & 3.93387600 & 1.77315300 \\
\hline $\mathrm{C}$ & 0.59508100 & 4.34178700 & 0.56248900 \\
\hline $\mathrm{C}$ & 0.33407300 & 3.37812200 & -0.39138000 \\
\hline $\mathrm{C}$ & 0.78743200 & 3.28563100 & -1.83993900 \\
\hline $\mathrm{C}$ & 4.56579700 & -1.51652400 & -2.65821500 \\
\hline $\mathrm{C}$ & 2.10622000 & -1.80165400 & -2.95411300 \\
\hline $\mathrm{C}$ & -0.14073500 & -3.32447700 & 1.57288500 \\
\hline $\mathrm{C}$ & 1.53943700 & -3.47997300 & 3.40766200 \\
\hline $\mathrm{C}$ & -1.90741300 & 2.66154100 & 3.68296800 \\
\hline $\mathrm{C}$ & -2.71176700 & 1.28135400 & 1.77202500 \\
\hline $\mathrm{C}$ & -0.36048100 & 2.80295900 & -2.74414700 \\
\hline $\mathrm{C}$ & 1.22415600 & 4.67857300 & -2.31068000 \\
\hline $\mathrm{H}$ & 0.92407500 & 0.48831300 & -1.91480700 \\
\hline $\mathrm{H}$ & 1.00120000 & -1.62670700 & -0.36900100 \\
\hline $\mathrm{H}$ & -0.70762000 & -0.59559900 & 1.27615200 \\
\hline $\mathrm{H}$ & -0.74249100 & 1.54762000 & -0.23636300 \\
\hline $\mathrm{H}$ & 3.79004500 & 3.58043800 & -2.01164300 \\
\hline $\mathrm{H}$ & 5.07679000 & 1.19421800 & -2.14198100 \\
\hline $\mathrm{H}$ & 5.18398300 & -2.04253000 & 0.01198300 \\
\hline $\mathrm{H}$ & 4.01679000 & -2.79940400 & 2.34100800 \\
\hline $\mathrm{H}$ & 1.48250100 & -1.09006000 & 4.84802500 \\
\hline $\mathrm{H}$ & 0.16027100 & 1.27882800 & 4.95198500 \\
\hline $\mathrm{H}$ & -0.04685500 & 4.48413600 & 2.71052900 \\
\hline $\mathrm{H}$ & 1.15050900 & 5.26277400 & 0.40504500 \\
\hline $\mathrm{H}$ & 5.38865000 & -1.08779800 & -2.06962500 \\
\hline $\mathrm{H}$ & 4.69833100 & -2.60753500 & -2.67930000 \\
\hline $\mathrm{H}$ & 4.64962600 & -1.12948200 & -3.68358400 \\
\hline
\end{tabular}




\begin{tabular}{|c|c|c|c|}
\hline $\mathrm{H}$ & 1.08787400 & -1.58779200 & -2.59837600 \\
\hline $\mathrm{H}$ & 2.18087300 & -1.41987600 & -3.98274500 \\
\hline $\mathrm{H}$ & 2.22899400 & -2.89413600 & -2.98120400 \\
\hline $\mathrm{H}$ & -0.95277900 & -3.53695200 & 2.28102800 \\
\hline $\mathrm{H}$ & -0.57594800 & -2.73931400 & 0.74947900 \\
\hline $\mathrm{H}$ & 0.21709600 & -4.27755200 & 1.15550300 \\
\hline $\mathrm{H}$ & 2.37319500 & -3.00883500 & 3.94670900 \\
\hline $\mathrm{H}$ & 0.73941900 & -3.68273400 & 4.13345600 \\
\hline $\mathrm{H}$ & 1.89859300 & -4.43549600 & 2.99971000 \\
\hline $\mathrm{H}$ & -1.05482200 & 3.08546300 & 4.23147400 \\
\hline $\mathrm{H}$ & -2.54569000 & 3.49372100 & 3.35411400 \\
\hline $\mathrm{H}$ & -2.47898300 & 2.03096000 & 4.37839400 \\
\hline $\mathrm{H}$ & -2.46442200 & 0.68819700 & 0.87972300 \\
\hline $\mathrm{H}$ & -3.27611500 & 0.62881100 & 2.45252700 \\
\hline $\mathrm{H}$ & -3.35878600 & 2.10799700 & 1.44755000 \\
\hline $\mathrm{H}$ & -0.71178900 & 1.79332100 & -2.48597700 \\
\hline $\mathrm{H}$ & -1.21963100 & 3.48295800 & -2.66509200 \\
\hline $\mathrm{H}$ & -0.02923700 & 2.77307400 & -3.79242200 \\
\hline $\mathrm{H}$ & 2.04656700 & 5.07963000 & -1.70194500 \\
\hline $\mathrm{H}$ & 1.56712300 & 4.63387400 & -3.35407300 \\
\hline $\mathrm{H}$ & 0.38114000 & 5.38076100 & -2.24514300 \\
\hline $\mathrm{C}$ & -3.89931100 & -2.01753400 & 0.52970400 \\
\hline $\mathrm{H}$ & -4.10719300 & -2.98776500 & 0.06838300 \\
\hline $\mathrm{H}$ & -3.01393100 & -1.55423600 & 0.07759400 \\
\hline $\mathrm{Cl}$ & -3.58852800 & -2.27899500 & 2.26099100 \\
\hline $\mathrm{Cl}$ & -5.29709300 & -0.95107500 & 0.25186000 \\
\hline $\mathrm{C}$ & -3.70678900 & 1.79652900 & -1.78118100 \\
\hline $\mathrm{H}$ & -2.80578200 & 1.24704100 & -1.48547000 \\
\hline $\mathrm{H}$ & -4.60068800 & 1.30208900 & -1.38928400 \\
\hline $\mathrm{Cl}$ & -3.79051500 & 1.79903200 & -3.55407400 \\
\hline $\mathrm{Cl}$ & -3.63263800 & 3.43821100 & -1.09571600 \\
\hline $\mathrm{C}$ & -0.67506700 & -3.96278300 & -1.96035600 \\
\hline $\mathrm{H}$ & -1.04021600 & -2.94332300 & -2.12493400 \\
\hline $\mathrm{H}$ & 0.21545500 & -3.95081000 & -1.32246300 \\
\hline $\mathrm{Cl}$ & -0.23488300 & -4.68718500 & -3.51912800 \\
\hline $\mathrm{Cl}$ & -1.94791700 & -4.87391700 & -1.10835400 \\
\hline $\mathrm{Cl}$ & -0.92770300 & -0.57832200 & -1.01728400 \\
\hline Cs & 2.48278300 & 1.18388400 & 1.31780300 \\
\hline
\end{tabular}


10

$E=-2746.2201241$

\begin{tabular}{|c|c|c|c|}
\hline $\mathrm{N}$ & -0.54082600 & 2.45641700 & 1.00579100 \\
\hline $\mathrm{N}$ & -2.93345900 & 0.24057700 & -0.12689900 \\
\hline $\mathrm{N}$ & -0.97067400 & -2.40147200 & 0.92130300 \\
\hline $\mathrm{N}$ & 1.40183700 & -0.18241100 & 2.02123000 \\
\hline $\mathrm{C}$ & 0.79453900 & 2.77330600 & 0.93458400 \\
\hline $\mathrm{C}$ & 0.97511100 & 3.50688900 & -0.22219900 \\
\hline $\mathrm{C}$ & -0.29433900 & 3.63525300 & -0.85402100 \\
\hline $\mathrm{C}$ & -1.22109200 & 2.97785700 & -0.06730700 \\
\hline $\mathrm{C}$ & -2.71237300 & 2.76516600 & -0.27382300 \\
\hline $\mathrm{C}$ & -2.95181400 & 1.39083900 & -0.87763300 \\
\hline $\mathrm{C}$ & -3.17151900 & 1.01572400 & -2.18920500 \\
\hline $\mathrm{C}$ & -3.29568100 & -0.40324200 & -2.21599400 \\
\hline $\mathrm{C}$ & -3.14879900 & -0.86002600 & -0.92027000 \\
\hline $\mathrm{C}$ & -3.15413400 & -2.27627700 & -0.36838900 \\
\hline $\mathrm{C}$ & -1.72349500 & -2.75191900 & -0.17249400 \\
\hline $\mathrm{C}$ & -0.91909900 & -3.52611500 & -0.98710000 \\
\hline $\mathrm{C}$ & 0.34948200 & -3.64569300 & -0.35151700 \\
\hline $\mathrm{C}$ & 0.28988600 & -2.94103500 & 0.83563200 \\
\hline $\mathrm{C}$ & 1.35246400 & -2.71789100 & 1.89972400 \\
\hline $\mathrm{C}$ & 2.01632500 & -1.36623600 & 1.69526300 \\
\hline $\mathrm{C}$ & 3.25500800 & -1.04913800 & 1.17235800 \\
\hline $\mathrm{C}$ & 3.38079700 & 0.37109700 & 1.19404600 \\
\hline $\mathrm{C}$ & 2.21576400 & 0.88503800 & 1.72886500 \\
\hline $\mathrm{C}$ & 1.80216000 & 2.32554600 & 1.98140300 \\
\hline $\mathrm{C}$ & -3.23407700 & 3.83016300 & -1.24700700 \\
\hline $\mathrm{C}$ & -3.46871500 & 2.90653500 & 1.06079200 \\
\hline $\mathrm{C}$ & -3.92963000 & -2.33252000 & 0.96158100 \\
\hline $\mathrm{C}$ & -3.84680200 & -3.19982300 & -1.37858600 \\
\hline $\mathrm{C}$ & 2.41596800 & -3.81531300 & 1.76831200 \\
\hline $\mathrm{C}$ & 0.73068400 & -2.79875700 & 3.30743800 \\
\hline $\mathrm{C}$ & 1.20797800 & 2.46823600 & 3.39634300 \\
\hline $\mathrm{C}$ & 3.04572900 & 3.21769500 & 1.87795800 \\
\hline $\mathrm{H}$ & -0.96296800 & 1.86590600 & 1.73098300 \\
\hline $\mathrm{H}$ & -2.73584800 & 0.20495000 & 0.87965200 \\
\hline $\mathrm{H}$ & -1.28755700 & -1.77422600 & 1.66907300 \\
\hline $\mathrm{H}$ & 0.45890400 & -0.10593600 & 2.42486500 \\
\hline $\mathrm{H}$ & 1.91283400 & 3.93206100 & -0.57006700 \\
\hline $\mathrm{H}$ & -0.50398800 & 4.17502500 & -1.77400700 \\
\hline $\mathrm{H}$ & -3.26178300 & 1.68734700 & -3.03925100 \\
\hline $\mathrm{H}$ & -3.49942400 & -1.01574800 & -3.09075400 \\
\hline $\mathrm{H}$ & -1.21383800 & -3.98465500 & -1.92768100 \\
\hline $\mathrm{H}$ & 1.20286100 & -4.21018500 & -0.71834700 \\
\hline $\mathrm{H}$ & 4.00888000 & -1.76439700 & 0.85101200 \\
\hline $\mathrm{H}$ & 4.24707500 & 0.95157700 & 0.88543900 \\
\hline $\mathrm{H}$ & -2.72921500 & 3.77942500 & -2.22171200 \\
\hline $\mathrm{H}$ & -4.31099600 & 3.69046500 & -1.41770700 \\
\hline $\mathrm{H}$ & -3.06785000 & 4.83459700 & -0.83228800 \\
\hline
\end{tabular}




$\begin{array}{lrrr}\mathrm{H} & -3.15072600 & 2.16944700 & 1.81257100 \\ \mathrm{H} & -3.30291900 & 3.90844700 & 1.48366400 \\ \mathrm{H} & -4.54757900 & 2.76937200 & 0.89580400 \\ \mathrm{H} & -3.93515700 & -3.36135300 & 1.35103200 \\ \mathrm{H} & -3.49661900 & -1.68373300 & 1.73717100 \\ \mathrm{H} & -4.96990000 & -2.01266600 & 0.80193900 \\ \mathrm{H} & -3.33386200 & -3.20438400 & -2.35041300 \\ \mathrm{H} & -3.86004400 & -4.23164700 & -0.99943700 \\ \mathrm{H} & -4.88222900 & -2.87018600 & -1.54513000 \\ \mathrm{H} & 2.89782400 & -3.80303500 & 0.78054800 \\ \mathrm{H} & 3.19790500 & -3.68026900 & 2.52942300 \\ \mathrm{H} & 1.95585700 & -4.80385800 & 1.90670800 \\ \mathrm{H} & -0.03591000 & -2.02859600 & 3.47810500 \\ \mathrm{H} & 0.25860300 & -3.78150600 & 3.45439600 \\ \mathrm{H} & 1.51207800 & -2.66667900 & 4.07043600 \\ \mathrm{H} & 0.31028100 & 1.85061200 & 3.54540200 \\ \mathrm{H} & 1.95144500 & 2.16193100 & 4.14693300 \\ \mathrm{H} & 0.93106000 & 3.51629900 & 3.58349300 \\ \mathrm{H} & 3.51516400 & 3.14913700 & 0.88640200 \\ \mathrm{H} & 2.77342500 & 4.26830200 & 2.05123600 \\ \mathrm{H} & 3.79145100 & 2.91793400 & 2.62800400 \\ \mathrm{C} & 3.97622800 & -0.24244200 & -2.31137900 \\ \mathrm{H} & 3.98018700 & -0.42367100 & -1.23114200 \\ \mathrm{H} & 4.98004400 & -0.29069100 & -2.74379100 \\ \mathrm{Cl} & 3.32746300 & 1.39148700 & -2.58056600 \\ \mathrm{Cl} & 2.98640500 & -1.51428200 & -3.07078300 \\ \mathrm{Cl} & -1.70020700 & 0.07646500 & 2.86184900 \\ \mathrm{Cs} & 0.24823300 & -0.01812900 & -1.10391400\end{array}$


11

$E=-3705.5995433$

\begin{tabular}{|c|c|c|c|}
\hline $\mathrm{N}$ & 0.45012900 & 0.13507100 & 2.60160500 \\
\hline $\mathrm{N}$ & 1.94235000 & 2.45605300 & 0.53861900 \\
\hline $\mathrm{N}$ & -0.26788200 & 1.64492300 & -1.97396100 \\
\hline $\mathrm{N}$ & -1.71801300 & -0.65164600 & 0.09154500 \\
\hline $\mathrm{C}$ & 0.06885500 & -1.18337100 & 2.67570300 \\
\hline $\mathrm{C}$ & 1.19164400 & -1.91010700 & 3.02156900 \\
\hline C & 2.27163400 & -0.99306500 & 3.16407500 \\
\hline C & 1.78169700 & 0.27267300 & 2.90421100 \\
\hline C & 2.49276400 & 1.61476800 & 2.86939100 \\
\hline C & 2.85558500 & 1.95461600 & 1.43404900 \\
\hline $\mathrm{C}$ & 4.05111200 & 1.81066200 & 0.75832900 \\
\hline C & 3.84422300 & 2.25081800 & -0.58033800 \\
\hline $\mathrm{C}$ & 2.52742300 & 2.65265500 & -0.68895900 \\
\hline $\mathrm{C}$ & 1.75374300 & 3.17475400 & -1.88762100 \\
\hline $\mathrm{C}$ & 0.93936500 & 2.04362500 & -2.49206100 \\
\hline $\mathrm{C}$ & 1.22234100 & 1.20404400 & -3.55241500 \\
\hline $\mathrm{C}$ & 0.14186700 & 0.28407100 & -3.67313000 \\
\hline $\mathrm{C}$ & -0.77530600 & 0.58362200 & -2.68400300 \\
\hline $\mathrm{C}$ & -2.11253300 & -0.05649200 & -2.35202000 \\
\hline $\mathrm{C}$ & -1.95409300 & -1.04209600 & -1.20505500 \\
\hline $\mathrm{C}$ & -1.99084800 & -2.42216800 & -1.21065400 \\
\hline $\mathrm{C}$ & -1.77786100 & -2.86539700 & 0.12761900 \\
\hline $\mathrm{C}$ & -1.61544800 & -1.74577500 & 0.91809000 \\
\hline $\mathrm{C}$ & -1.35740900 & -1.63693400 & 2.41266600 \\
\hline $\mathrm{C}$ & 3.78119500 & 1.51661200 & 3.69605500 \\
\hline $\mathrm{C}$ & 1.60428000 & 2.71699100 & 3.47646900 \\
\hline $\mathrm{C}$ & 0.83761600 & 4.34161800 & -1.47250800 \\
\hline $\mathrm{C}$ & 2.74974000 & 3.68417500 & -2.93708200 \\
\hline $\mathrm{C}$ & -2.61364400 & -0.81530200 & -3.58738300 \\
\hline $\mathrm{C}$ & -3.14530400 & 1.02893400 & -1.99769200 \\
\hline $\mathrm{C}$ & -2.34903900 & -0.65286300 & 3.06343900 \\
\hline $\mathrm{C}$ & -1.55446700 & -3.01999100 & 3.04555100 \\
\hline $\mathrm{H}$ & -0.16305800 & 0.90519100 & 2.31681200 \\
\hline $\mathrm{H}$ & 0.95290700 & 2.62281300 & 0.74653400 \\
\hline $\mathrm{H}$ & -0.71309600 & 2.05865400 & -1.14955600 \\
\hline $\mathrm{H}$ & -1.66123300 & 0.32546300 & 0.40505500 \\
\hline $\mathrm{H}$ & 1.23350600 & -2.98423800 & 3.18158700 \\
\hline $\mathrm{H}$ & 3.29125200 & -1.23685600 & 3.45170300 \\
\hline $\mathrm{H}$ & 4.98572800 & 1.45353400 & 1.18331800 \\
\hline $\mathrm{H}$ & 4.59320200 & 2.29253300 & -1.36702900 \\
\hline $\mathrm{H}$ & 2.09915000 & 1.25695300 & -4.19295700 \\
\hline $\mathrm{H}$ & 0.03898300 & -0.49303200 & -4.42612000 \\
\hline $\mathrm{H}$ & -2.19349100 & -3.04787900 & -2.07673400 \\
\hline $\mathrm{H}$ & -1.77904500 & -3.89475000 & 0.47803700 \\
\hline $\mathrm{H}$ & 4.46065700 & 0.74357000 & 3.31096700 \\
\hline $\mathrm{H}$ & 4.31709100 & 2.47618600 & 3.67507100 \\
\hline $\mathrm{H}$ & 3.54344200 & 1.26692200 & 4.73992100 \\
\hline
\end{tabular}




$\begin{array}{lrrr}\mathrm{H} & 0.65449800 & 2.84897000 & 2.93783400 \\ \mathrm{H} & 1.36487800 & 2.47418600 & 4.52237600 \\ \mathrm{H} & 2.13555500 & 3.67984300 & 3.45396200 \\ \mathrm{H} & 0.29228100 & 4.72181600 & -2.34885600 \\ \mathrm{H} & 0.09381000 & 4.05512200 & -0.71461700 \\ \mathrm{H} & 1.44080200 & 5.16000000 & -1.05270800 \\ \mathrm{H} & 3.43585400 & 2.89310800 & -3.27032900 \\ \mathrm{H} & 2.21178600 & 4.05790200 & -3.81982900 \\ \mathrm{H} & 3.35515800 & 4.50081600 & -2.51873500 \\ \mathrm{H} & -1.91727000 & -1.60867300 & -3.89375600 \\ \mathrm{H} & -3.58843100 & -1.27843400 & -3.37843700 \\ \mathrm{H} & -2.72848300 & -0.12107800 & -4.43158900 \\ \mathrm{H} & -2.85113400 & 1.62317900 & -1.12039400 \\ \mathrm{H} & -3.26648100 & 1.72543700 & -2.84040600 \\ \mathrm{H} & -4.11817100 & 0.56850800 & -1.77850400 \\ \mathrm{H} & -2.26753000 & 0.35952300 & 2.64142100 \\ \mathrm{H} & -3.37912000 & -1.00244100 & 2.90619300 \\ \mathrm{H} & -2.15513200 & -0.58147300 & 4.14399000 \\ \mathrm{H} & -0.86423200 & -3.76347600 & 2.62222600 \\ \mathrm{H} & -1.37333100 & -2.96718100 & 4.12828400 \\ \mathrm{H} & -2.58189500 & -3.37267900 & 2.87694700 \\ \mathrm{C} & -4.84105700 & 1.21688800 & 1.17471300 \\ \mathrm{H} & -5.12388500 & 1.34347900 & 2.22451700 \\ \mathrm{H} & -3.77279600 & 1.41915400 & 1.03256400 \\ \mathrm{Cl} & -5.75967500 & 2.38660900 & 0.20647900 \\ \mathrm{Cl} & -5.17998900 & -0.47018000 & 0.71547400 \\ \mathrm{C} & 1.04291900 & -4.42576800 & -1.42788400 \\ \mathrm{H} & 0.87664300 & -5.47041200 & -1.70729000 \\ \mathrm{H} & 0.10173100 & -3.87773800 & -1.30116900 \\ \mathrm{Cl} & 1.96695700 & -3.63926500 & -2.73488100 \\ \mathrm{Cl} & 1.90292600 & -4.39258700 & 0.13100000 \\ \mathrm{Cl} & -1.29238600 & 2.39021500 & 1.03585200 \\ \mathrm{Cs} & 1.56188500 & -0.73432600 & -0.46128000\end{array}$


12

$E=-4664.9806609$

$\mathrm{N}$

$\mathrm{N}$

$\mathrm{N}$

$\mathrm{N}$

C

C

C

C

C

C

C

C

C

C

C

C

C

C

C

C

C

C

C

C

C

C

C

C

C

C

C

C

$\mathrm{H}$

$\mathrm{H}$

$\mathrm{H}$

$\mathrm{H}$

$\mathrm{H}$

$\mathrm{H}$

$\mathrm{H}$

$\mathrm{H}$

$\mathrm{H}$

$\mathrm{H}$

$\mathrm{H}$

$\mathrm{H}$

$\mathrm{H}$

$\mathrm{H}$

$\mathrm{H}$

\begin{tabular}{|c|c|c|}
\hline 1.35002000 & 0.04958000 & -2.60977500 \\
\hline 0.11259300 & -2.79395500 & -1.08529900 \\
\hline 19684800 & -0.84657400 & 1.43678700 \\
\hline 0.04479700 & 1.95199200 & -0.07875500 \\
\hline 2.11158900 & 1.17253600 & -2.38846300 \\
\hline 43452400 & 0.79058900 & -2.49424700 \\
\hline .45920800 & -0.60100000 & -2.79556400 \\
\hline 2.15019100 & -1.03655000 & -2.86846800 \\
\hline 1.58720700 & -2.42569400 & -3.11815600 \\
\hline 1.25820800 & -3.08163800 & -1.78803200 \\
\hline 1.98205000 & -3.98149400 & -1.03097700 \\
\hline 1.23740900 & -4.24422000 & 0.15511700 \\
\hline 0.07626400 & -3.49887400 & 0.09430100 \\
\hline 06228000 & -3.36277500 & 1.09086200 \\
\hline 87081000 & -2.09528600 & 1.90859900 \\
\hline 32821100 & -1.92207300 & 3.16699900 \\
\hline 0.34420300 & -0.52795900 & 3.45602500 \\
\hline .89579700 & 0.11951000 & 2.36820800 \\
\hline-1.15259400 & 1.59971000 & 2.13657500 \\
\hline-0.05664600 & 2.19662100 & 1.26937200 \\
\hline 0.99061300 & 3.03075800 & 1.60711400 \\
\hline 1.73344900 & 3.29514100 & 13000 \\
\hline 1.12136700 & 2.61699400 & -0.61558200 \\
\hline 1.49919400 & 2.52962200 & -2.08561800 \\
\hline 2.64854500 & -3.26756800 & -3.83802800 \\
\hline 0.33322700 & -2.35163100 & -4.00958500 \\
\hline-2.41576200 & -3.34555500 & 0.35 \\
\hline-1.03935600 & -4.56820300 & 2.03910400 \\
\hline-1.15048400 & 2.31595000 & 3.49284600 \\
\hline-2.52633500 & 1.81111100 & 1.47769500 \\
\hline 0.26766400 & 2.76580400 & -2.98007300 \\
\hline 2.53856600 & 3.61611200 & -2.38936600 \\
\hline 0.32913800 & 0.01818000 & -2.55102000 \\
\hline-0.60381900 & -2.12913100 & -1.38679900 \\
\hline-1.58212200 & -0.65959400 & 0.50799900 \\
\hline-0.61434800 & 1.38069500 & -0.61761300 \\
\hline 4.29711800 & 1.44392000 & -2.39338500 \\
\hline 4.34524300 & -1.20730100 & -2.96595000 \\
\hline 2.93389100 & -4.42864700 & -1.30636500 \\
\hline 1.51539900 & -4.92999300 & 0.95142800 \\
\hline 0.01906700 & -2.71195700 & 3.82803700 \\
\hline-0.01091800 & -0.05791900 & 4.37747700 \\
\hline 1.17421900 & 3.44740100 & 2.59485200 \\
\hline 2.60419900 & 3.94001000 & 0.32813400 \\
\hline 3.57158000 & -3.35759800 & -3.24871300 \\
\hline 2.26565000 & -4.28154700 & -4.02141200 \\
\hline 2.90721100 & -2.80557500 & -4.80134200 \\
\hline
\end{tabular}




$\begin{array}{lccc}\mathrm{H} & -0.47928100 & -1.76124800 & -3.56116800 \\ \mathrm{H} & 0.58484100 & -1.89045800 & -4.97597600 \\ \mathrm{H} & -0.05629500 & -3.36353000 & -4.19408900 \\ \mathrm{H} & -3.23689700 & -3.22667000 & 1.07863400 \\ \mathrm{H} & -2.49480000 & -2.53001100 & -0.37515400 \\ \mathrm{H} & -2.55988500 & -4.28896800 & -0.18807800 \\ \mathrm{H} & -0.09143200 & -4.64039300 & 2.59034400 \\ \mathrm{H} & -1.85246600 & -4.48526300 & 2.77404900 \\ \mathrm{H} & -1.16992200 & -5.49980400 & 1.47049800 \\ \mathrm{H} & -0.18919000 & 2.20308700 & 4.01396600 \\ \mathrm{H} & -1.33972200 & 3.38977500 & 3.35353100 \\ \mathrm{H} & -1.93654500 & 1.90064700 & 4.13876300 \\ \mathrm{H} & -2.59288400 & 1.31863000 & 0.49678200 \\ \mathrm{H} & -3.32160600 & 1.39509500 & 2.11142400 \\ \mathrm{H} & -2.71208000 & 2.88253900 & 1.32180700 \\ \mathrm{H} & -0.52253600 & 2.01880000 & -2.81342400 \\ \mathrm{H} & -0.16505700 & 3.75510500 & -2.77719200 \\ \mathrm{H} & 0.55859500 & 2.71261900 & -4.03984600 \\ \mathrm{H} & 3.44510000 & 3.49687400 & -1.77955300 \\ \mathrm{H} & 2.83409200 & 3.56915200 & -3.44699600 \\ \mathrm{H} & 2.11757500 & 4.61072600 & -2.18456300 \\ \mathrm{C} & -4.94386800 & -0.74022900 & 0.17298300 \\ \mathrm{H} & -3.92741600 & -0.63049300 & -0.22250400 \\ \mathrm{H} & -5.52116000 & 0.17262800 & -0.00320400 \\ \mathrm{Cl} & -4.85800900 & -1.01276400 & 1.93084800 \\ \mathrm{Cl} & -5.72491400 & -2.08262200 & -0.68644900 \\ \mathrm{C} & -3.54360800 & 3.06751500 & -1.79441800 \\ \mathrm{H} & -3.78830000 & 3.31160800 & -2.83296800 \\ \mathrm{H} & -3.00852700 & 2.11120000 & -1.72971000 \\ \mathrm{Cl} & -5.07082200 & 2.92101000 & -0.89184000 \\ \mathrm{Cl} & -2.50236900 & 4.36060700 & -1.15682700 \\ \mathrm{C} & 4.26601000 & 1.89293300 & 2.58819000 \\ \mathrm{H} & 3.35646100 & 2.41798000 & 2.27618300 \\ \mathrm{H} & 4.93888800 & 2.53513600 & 3.16417700 \\ \mathrm{Cl} & 5.11570100 & 1.36733100 & 1.11586400 \\ \mathrm{Cl} & 3.77592600 & 0.53174600 & 3.62773400 \\ \mathrm{Cl} & -0.17391600 & -1.70116600 \\ & -0.63250200 & 0.61310400\end{array}$


13

$E=-5624.3620234$

\begin{tabular}{|c|c|c|c|}
\hline $\mathrm{N}$ & -0.71546600 & -0.32081400 & 2.84316300 \\
\hline $\mathrm{N}$ & 0.29555900 & -2.67506200 & 0.53221300 \\
\hline $\mathrm{N}$ & 0.25595900 & -0.27037600 & -1.93244800 \\
\hline $\mathrm{N}$ & -0.73331100 & 2.05461200 & 0.35544300 \\
\hline $\mathrm{C}$ & -1.66450700 & 0.64230700 & 3.08989700 \\
\hline C & -2.78084800 & -0.00743800 & 3.57848900 \\
\hline $\mathrm{C}$ & -2.48124300 & -1.39945400 & 3.63317500 \\
\hline $\mathrm{C}$ & -1.18855100 & -1.56712900 & 3.17669500 \\
\hline $\mathrm{C}$ & -0.36329900 & -2.82791200 & 2.98521200 \\
\hline $\mathrm{C}$ & -0.44181900 & -3.26497700 & 1.53145900 \\
\hline C & -1.24519400 & -4.21538800 & 0.93254300 \\
\hline $\mathrm{C}$ & -0.96744200 & -4.19773800 & -0.46420300 \\
\hline $\mathrm{C}$ & -0.00066400 & -3.23725100 & -0.68714800 \\
\hline $\mathrm{C}$ & 0.64774800 & -2.78153400 & -1.98392700 \\
\hline $\mathrm{C}$ & -0.01764000 & -1.50548100 & -2.47288900 \\
\hline $\mathrm{C}$ & -0.97832500 & -1.31649500 & -3.44526300 \\
\hline $\mathrm{C}$ & -1.27261300 & 0.07605600 & -3.49614300 \\
\hline $\mathrm{C}$ & -0.48778500 & 0.70575400 & -2.55004300 \\
\hline $\mathrm{C}$ & -0.40366400 & 2.17234700 & -2.16396200 \\
\hline $\mathrm{C}$ & -1.19270600 & 2.41720500 & -0.88897500 \\
\hline $\mathrm{C}$ & -2.43895200 & 2.98267900 & -0.70859500 \\
\hline $\mathrm{C}$ & -2.72461100 & 2.96682800 & 0.68634800 \\
\hline $\mathrm{C}$ & -1.64632800 & 2.39498800 & 1.32783900 \\
\hline $\mathrm{C}$ & -1.42387400 & 2.11439900 & 2.80537600 \\
\hline $\mathrm{C}$ & -0.94324200 & -3.93932400 & 3.86910900 \\
\hline $\mathrm{C}$ & 1.09615900 & -2.58079500 & 3.40789400 \\
\hline $\mathrm{C}$ & 2.15662100 & -2.56199700 & -1.78332900 \\
\hline $\mathrm{C}$ & 0.45476900 & -3.87503100 & -3.04235300 \\
\hline $\mathrm{C}$ & -1.01131500 & 3.01555000 & -3.29150600 \\
\hline $\mathrm{C}$ & 1.06273700 & 2.59840600 & -1.97922900 \\
\hline $\mathrm{C}$ & 0.00065300 & 2.51315700 & 3.23020800 \\
\hline $\mathrm{C}$ & -2.42158200 & 2.94708100 & 3.62033700 \\
\hline $\mathrm{H}$ & 0.20827400 & -0.13892000 & 2.44682600 \\
\hline $\mathrm{H}$ & 0.96938200 & -1.92020700 & 0.67417800 \\
\hline $\mathrm{H}$ & 0.93437100 & -0.10133400 & -1.18696100 \\
\hline $\mathrm{H}$ & 0.16421100 & 1.59913300 & 0.53456800 \\
\hline $\mathrm{H}$ & -3.70804500 & 0.46577400 & 3.89151300 \\
\hline $\mathrm{H}$ & -3.13847600 & -2.18646000 & 3.99442800 \\
\hline $\mathrm{H}$ & -1.94272200 & -4.87506300 & 1.44228200 \\
\hline $\mathrm{H}$ & -1.41123600 & -4.84340100 & -1.21755200 \\
\hline $\mathrm{H}$ & -1.41201100 & -2.08848000 & -4.07509700 \\
\hline $\mathrm{H}$ & -1.95619500 & 0.56228000 & -4.18767900 \\
\hline $\mathrm{H}$ & -3.06752900 & 3.40822800 & -1.48699900 \\
\hline $\mathrm{H}$ & -3.61913600 & 3.35788200 & 1.16301200 \\
\hline $\mathrm{H}$ & -1.99375400 & -4.15168200 & 3.62665200 \\
\hline $\mathrm{H}$ & -0.37160600 & -4.86821800 & 3.73285200 \\
\hline $\mathrm{H}$ & -0.89483100 & -3.64492800 & 4.92716000 \\
\hline
\end{tabular}




\begin{tabular}{|c|c|c|c|}
\hline $\mathrm{H}$ & 1.58383100 & -1.79209900 & 2.81634800 \\
\hline $\mathrm{H}$ & 1.13346900 & -2.27505400 & 4.46397900 \\
\hline $\mathrm{H}$ & 1.68747600 & -3.49809500 & 3.28192300 \\
\hline $\mathrm{H}$ & 2.62951500 & -2.26048100 & -2.72778500 \\
\hline $\mathrm{H}$ & 2.37310200 & -1.77247000 & -1.04909900 \\
\hline $\mathrm{H}$ & 2.63161900 & -3.48532400 & -1.42386600 \\
\hline $\mathrm{H}$ & -0.60785400 & -4.08115900 & -3.23204000 \\
\hline $\mathrm{H}$ & 0.91475500 & -3.56583200 & -3.99146000 \\
\hline $\mathrm{H}$ & 0.92726900 & -4.80939900 & -2.70815300 \\
\hline $\mathrm{H}$ & -2.06607300 & 2.76427600 & -3.47506900 \\
\hline $\mathrm{H}$ & -0.96005000 & 4.08302300 & -3.03528300 \\
\hline $\mathrm{H}$ & -0.45944300 & 2.84904000 & -4.22709700 \\
\hline $\mathrm{H}$ & 1.55609000 & 2.03881600 & -1.17152400 \\
\hline $\mathrm{H}$ & 1.63414800 & 2.41919700 & -2.90038000 \\
\hline $\mathrm{H}$ & 1.11676500 & 3.66548200 & -1.72271100 \\
\hline $\mathrm{H}$ & 0.77881000 & 1.94273200 & 2.70251900 \\
\hline $\mathrm{H}$ & 0.17389500 & 3.57891600 & 3.02750400 \\
\hline $\mathrm{H}$ & 0.13853600 & 2.33266700 & 4.30630300 \\
\hline $\mathrm{H}$ & -3.46379000 & 2.70816200 & 3.36623300 \\
\hline $\mathrm{H}$ & -2.28281600 & 2.75599300 & 4.69378700 \\
\hline $\mathrm{H}$ & -2.26282100 & 4.01767900 & 3.42878700 \\
\hline $\mathrm{C}$ & -4.76972800 & 0.76889300 & -2.48469100 \\
\hline $\mathrm{H}$ & -5.31946100 & 1.32800700 & -3.24816200 \\
\hline $\mathrm{H}$ & -3.73047000 & 1.11517000 & -2.40724200 \\
\hline $\mathrm{Cl}$ & -4.75600400 & -0.94753400 & -2.95260200 \\
\hline $\mathrm{Cl}$ & -5.56444000 & 1.03790300 & -0.91596500 \\
\hline $\mathrm{C}$ & 4.35409800 & 1.01897600 & -1.75384400 \\
\hline $\mathrm{H}$ & 3.60451800 & 0.83593700 & -0.97392900 \\
\hline $\mathrm{H}$ & 5.28102400 & 0.48078000 & -1.53464600 \\
\hline $\mathrm{Cl}$ & 4.71733400 & 2.76256200 & -1.79454900 \\
\hline $\mathrm{Cl}$ & 3.72155700 & 0.42644500 & -3.30499500 \\
\hline $\mathrm{C}$ & 2.53771500 & 3.85629600 & 1.09558100 \\
\hline $\mathrm{H}$ & 2.11436500 & 2.84743300 & 1.04214400 \\
\hline $\mathrm{H}$ & 3.30601300 & 3.98879400 & 0.32737600 \\
\hline $\mathrm{Cl}$ & 3.29156500 & 4.04872700 & 2.69097500 \\
\hline $\mathrm{Cl}$ & 1.24127200 & 5.04051200 & 0.80235700 \\
\hline $\mathrm{C}$ & 4.54637600 & -2.33874500 & 1.05298000 \\
\hline $\mathrm{H}$ & 5.22000800 & -2.18337800 & 1.90151100 \\
\hline $\mathrm{H}$ & 3.75897100 & -1.57478700 & 1.02226200 \\
\hline $\mathrm{Cl}$ & 3.78860200 & -3.93627300 & 1.23636500 \\
\hline $\mathrm{Cl}$ & 5.50936600 & -2.21425200 & -0.43969200 \\
\hline $\mathrm{Cl}$ & 1.91309000 & 0.17832700 & 0.87631100 \\
\hline Cs & -2.42721400 & -0.81330300 & 0.00451300 \\
\hline
\end{tabular}


20

$E=-3705.6058088$

\begin{tabular}{|c|c|c|c|}
\hline $\mathrm{N}$ & -0.06758200 & 2.81245100 & 0.48709700 \\
\hline $\mathrm{N}$ & -0.45470400 & 0.15709100 & 2.59386700 \\
\hline $\mathrm{N}$ & 2.37795900 & -1.31354500 & 1.32113900 \\
\hline $\mathrm{N}$ & 2.77851400 & 1.36177100 & -0.82640000 \\
\hline $\mathrm{C}$ & 0.08947500 & 3.17613100 & -0.82875400 \\
\hline $\mathrm{C}$ & -1.17107200 & 3.21599200 & -1.39153100 \\
\hline $\mathrm{C}$ & -2.10844300 & 2.87907900 & -0.37330300 \\
\hline $\mathrm{C}$ & -1.39576000 & 2.63390800 & 0.78663600 \\
\hline C & -1.87623700 & 2.21894700 & 2.16830700 \\
\hline $\mathrm{C}$ & -1.68386600 & 0.72264000 & 2.35493700 \\
\hline $\mathrm{C}$ & -2.60246400 & -0.30863600 & 2.31264700 \\
\hline $\mathrm{C}$ & -1.89587900 & -1.52515700 & 2.53613300 \\
\hline $\mathrm{C}$ & -0.56373900 & -1.20734500 & 2.71572300 \\
\hline $\mathrm{C}$ & 0.63449300 & -2.10002900 & 2.99642300 \\
\hline $\mathrm{C}$ & 1.47683300 & -2.26269500 & 1.74126300 \\
\hline $\mathrm{C}$ & 1.50952000 & -3.28877500 & 0.81672400 \\
\hline $\mathrm{C}$ & 2.46271700 & -2.94038000 & -0.18112500 \\
\hline $\mathrm{C}$ & 2.99216700 & -1.71019900 & 0.15816400 \\
\hline $\mathrm{C}$ & 4.01000200 & -0.84409900 & -0.56703500 \\
\hline $\mathrm{C}$ & 3.28442700 & 0.21276400 & -1.38389200 \\
\hline $\mathrm{C}$ & 2.94862600 & 0.23058600 & -2.72427900 \\
\hline $\mathrm{C}$ & 2.22592700 & 1.43271700 & -2.97140000 \\
\hline $\mathrm{C}$ & 2.13671000 & 2.11996000 & -1.77583100 \\
\hline $\mathrm{C}$ & 1.45306900 & 3.43770100 & -1.44927300 \\
\hline $\mathrm{C}$ & -3.37036600 & 2.54544800 & 2.28844100 \\
\hline $\mathrm{C}$ & -1.11403000 & 2.99570300 & 3.25971700 \\
\hline $\mathrm{C}$ & 1.48232300 & -1.50691100 & 4.13863200 \\
\hline $\mathrm{C}$ & 0.12681400 & -3.48159600 & 3.42843500 \\
\hline $\mathrm{C}$ & 4.82606800 & -1.72954300 & -1.51752700 \\
\hline $\mathrm{C}$ & 4.97351000 & -0.18437800 & 0.43759300 \\
\hline $\mathrm{C}$ & 2.32594300 & 4.27355500 & -0.49353300 \\
\hline $\mathrm{C}$ & 1.25738400 & 4.22598200 & -2.75075400 \\
\hline $\mathrm{H}$ & 0.70492600 & 2.66050000 & 1.14621000 \\
\hline $\mathrm{H}$ & 0.42577000 & 0.68203600 & 2.66905000 \\
\hline $\mathrm{H}$ & 2.53090400 & -0.40869300 & 1.78011200 \\
\hline $\mathrm{H}$ & 2.82200900 & 1.59290600 & 0.17278400 \\
\hline $\mathrm{H}$ & -1.40654800 & 3.48496800 & -2.41784300 \\
\hline $\mathrm{H}$ & -3.19108400 & 2.86298500 & -0.47863000 \\
\hline $\mathrm{H}$ & -3.67624500 & -0.19997400 & 2.17833500 \\
\hline $\mathrm{H}$ & -2.32977400 & -2.51988100 & 2.60112000 \\
\hline $\mathrm{H}$ & 0.92640100 & -4.20488000 & 0.85771500 \\
\hline $\mathrm{H}$ & 2.74030500 & -3.54103200 & -1.04334300 \\
\hline $\mathrm{H}$ & 3.21423600 & -0.52478800 & -3.45948200 \\
\hline $\mathrm{H}$ & 1.83661600 & 1.76514700 & -3.93034800 \\
\hline $\mathrm{H}$ & -3.97639000 & 2.01801400 & 1.53804500 \\
\hline $\mathrm{H}$ & -3.74237800 & 2.25739600 & 3.28197800 \\
\hline $\mathrm{H}$ & -3.53243600 & 3.62363000 & 2.14985300 \\
\hline
\end{tabular}




$\begin{array}{lrrr}\mathrm{H} & -0.03082400 & 2.80629500 & 3.23992900 \\ \mathrm{H} & -1.26895700 & 4.07675100 & 3.12783800 \\ \mathrm{H} & -1.48658400 & 2.70581600 & 4.25327200 \\ \mathrm{H} & 2.33864200 & -2.16405800 & 4.35126400 \\ \mathrm{H} & 1.87666300 & -0.50780800 & 3.90191800 \\ \mathrm{H} & 0.87357700 & -1.41761500 & 5.05053800 \\ \mathrm{H} & -0.49118800 & -3.95155000 & 2.65032400 \\ \mathrm{H} & 0.97570500 & -4.14892200 & 3.63395300 \\ \mathrm{H} & -0.48270400 & -3.39449800 & 4.33919100 \\ \mathrm{H} & 4.19018300 & -2.22804400 & -2.26236100 \\ \mathrm{H} & 5.56533300 & -1.12224100 & -2.05903900 \\ \mathrm{H} & 5.35402600 & -2.50873700 & -0.94948700 \\ \mathrm{H} & 4.45913500 & 0.46910200 & 1.15734300 \\ \mathrm{H} & 5.50712800 & -0.95797500 & 1.00936600 \\ \mathrm{H} & 5.71293500 & 0.42791600 & -0.09944700 \\ \mathrm{H} & 2.50658000 & 3.77127700 & 0.46820900 \\ \mathrm{H} & 3.30386700 & 4.47190100 & -0.95652000 \\ \mathrm{H} & 1.83563800 & 5.23527800 & -0.28215900 \\ \mathrm{H} & 0.63330600 & 3.67890500 & -3.47104300 \\ \mathrm{H} & 0.76669300 & 5.18721400 & -2.54186000 \\ \mathrm{H} & 2.22975100 & 4.41978200 & -3.22534100 \\ \mathrm{C} & -2.02841000 & -3.65001900 & -2.30075500 \\ \mathrm{H} & -2.21249100 & -4.71018100 & -2.49919100 \\ \mathrm{H} & -2.77986400 & -3.00978600 & -2.77397100 \\ \mathrm{Cl} & -0.43859100 & -3.22689500 & -2.97292500 \\ \mathrm{Cl} & -2.12530400 & -3.39021100 & -0.54137000 \\ \mathrm{C} & -3.85012300 & -0.11576800 & -0.81064700 \\ \mathrm{H} & -3.86211000 & -1.13190100 & -0.40476100 \\ \mathrm{H} & -3.12632400 & 0.51688200 & -0.28574200 \\ \mathrm{Cl} & -5.44663700 & 0.61447100 & -0.61405300 \\ \mathrm{Cl} & -3.33562400 & -0.21757600 & -2.52376600 \\ \mathrm{Cl} & 2.34423200 & 1.74994500 & 2.35488600 \\ \mathrm{Cs} & -0.08135900 & -0.32700900 & -0.69301100\end{array}$


21

$E=-4664.9861128$

$\mathrm{N}$

$\mathrm{N}$

$\mathrm{N}$

$\mathrm{N}$

C

C

C

C

C

C

C

C

C

C

C

C

C

C

C

C

C

C

C

C

C

C

C

C

C

C

C

C

$\mathrm{H}$

$\mathrm{H}$

$\mathrm{H}$

$\mathrm{H}$

$\mathrm{H}$

$\mathrm{H}$

$\mathrm{H}$

$\mathrm{H}$

H

$\mathrm{H}$

$\mathrm{H}$

$\mathrm{H}$

$\mathrm{H}$

$\mathrm{H}$

$\mathrm{H}$

$\begin{array}{ccc}-1.85298700 & 0.49905300 & -1.37081400 \\ -1.19473000 & -2.27046700 & 0.58421700 \\ 0.27035800 & -0.23462900 & 2.97099800 \\ -0.35177600 & 2.49221900 & 0.98724300 \\ -1.26129400 & 1.60258300 & -1.93730800 \\ -0.64211600 & 1.17700300 & -3.09716000 \\ -0.88181900 & -0.21976800 & -3.22693300 \\ -1.64190000 & -0.61673300 & -2.14319100 \\ -2.14527200 & -1.99849000 & -1.75337300 \\ -1.19584600 & -2.62296400 & -0.74472900 \\ -0.19514100 & -3.55858800 & -0.91657600 \\ 0.41608500 & -3.77418300 & 0.35103500 \\ -0.22571100 & -2.96557700 & 1.26773800 \\ 0.03993800 & -2.75515800 & 2.74893400 \\ 0.84662200 & -1.48120600 & 2.94480300 \\ 2.21042200 & -1.29862600 & 3.07225200 \\ 2.44989200 & 0.09988000 & 3.18579700 \\ 1.22696100 & 0.74002200 & 3.12438200 \\ 0.89155800 & 2.22149600 & 3.18146800 \\ 0.73599400 & 2.77660700 & 1.77600300 \\ 1.56597100 & 3.59813800 & 1.03916000 \\ 0.94725000 & 3.81040700 & -0.22912000 \\ -0.24467200 & 3.11360400 & -0.23290600 \\ -1.31046600 & 2.98639600 & -1.30820700 \\ -2.18179900 & -2.87830700 & -3.00921400 \\ -3.56557600 & -1.91915400 & -1.16752900 \\ -1.28548000 & -2.68445300 & 3.53057500 \\ 0.85749000 & -3.94039100 & 3.27815900 \\ 2.04205700 & 2.95738200 & 3.87994500 \\ -0.40180300 & 2.45187700 & 3.98753700 \\ -2.69855500 & 3.26433200 & -0.70152900 \\ -1.03697400 & 4.03005900 & -2.39871600 \\ -2.35428100 & 0.49949400 & -0.47868200 \\ -1.81141100 & -1.56707500 & 1.00107800 \\ -0.72860200 & -0.05378000 & 2.83696400 \\ -1.14853400 & 1.91232600 & 1.27778900 \\ -0.08929700 & 1.80282400 & -3.79281800 \\ -0.54614900 & -0.85842500 & -4.03976500 \\ 0.06647900 & -4.05086300 & -1.84928600 \\ 1.22871300 & -4.46330200 & 0.56469500 \\ 2.96075700 & -2.08434000 & 3.10154800 \\ 3.41622500 & 0.57889200 & 3.31999000 \\ 2.49786800 & 4.03554200 & 1.39049100 \\ 1.31613400 & 4.43974100 & -1.03582400 \\ -182000 & -2.97649500 & -3.47097200 \\ -3.88727600 & -2.75382100 \\ -2.44321200 & -3.75497100\end{array}$




\begin{tabular}{|c|c|c|c|}
\hline $\mathrm{H}$ & -3.61063000 & -1.32784500 & -0.24148600 \\
\hline $\mathrm{H}$ & -4.25589700 & -1.45765000 & -1.88726900 \\
\hline $\mathrm{H}$ & -3.93017500 & -2.92833000 & -0.92662000 \\
\hline $\mathrm{H}$ & -1.08491100 & -2.53659500 & 4.60213200 \\
\hline $\mathrm{H}$ & -1.93807300 & -1.86459200 & 3.19607900 \\
\hline $\mathrm{H}$ & -1.84263000 & -3.62424700 & 3.40411000 \\
\hline $\mathrm{H}$ & 1.81894000 & -4.04109000 & 2.75563500 \\
\hline $\mathrm{H}$ & 1.06716900 & -3.80635900 & 4.34895500 \\
\hline $\mathrm{H}$ & 0.30020300 & -4.87772700 & 3.13948900 \\
\hline $\mathrm{H}$ & 2.99294900 & 2.83530800 & 3.34225300 \\
\hline $\mathrm{H}$ & 1.82423500 & 4.03317300 & 3.94414800 \\
\hline $\mathrm{H}$ & 2.17773400 & 2.56354400 & 4.89704200 \\
\hline $\mathrm{H}$ & -1.27930900 & 1.97184800 & 3.53021200 \\
\hline $\mathrm{H}$ & -0.28869500 & 2.04797000 & 5.00462300 \\
\hline $\mathrm{H}$ & -0.61104800 & 3.52941500 & 4.05832300 \\
\hline $\mathrm{H}$ & -2.95640200 & 2.55940000 & 0.10192100 \\
\hline $\mathrm{H}$ & -2.72187000 & 4.27793800 & -0.27443800 \\
\hline $\mathrm{H}$ & -3.47666400 & 3.18506200 & -1.47346300 \\
\hline $\mathrm{H}$ & -0.05025600 & 3.88890900 & -2.86233300 \\
\hline $\mathrm{H}$ & -1.79682300 & 3.95532600 & -3.18907500 \\
\hline $\mathrm{H}$ & -1.07030500 & 5.04253500 & -1.97140100 \\
\hline $\mathrm{C}$ & 4.19693000 & -1.99094000 & -2.19257000 \\
\hline $\mathrm{H}$ & 4.93215400 & -2.60805700 & -2.71776800 \\
\hline $\mathrm{H}$ & 4.52438600 & -0.94778100 & -2.12063300 \\
\hline $\mathrm{Cl}$ & 4.01662100 & -2.62334000 & -0.54024500 \\
\hline $\mathrm{Cl}$ & 2.67836800 & -2.02558100 & -3.11723700 \\
\hline $\mathrm{C}$ & -5.94980200 & 0.63233800 & 0.26089400 \\
\hline $\mathrm{H}$ & -6.62335100 & 1.37156800 & 0.70568700 \\
\hline $\mathrm{H}$ & -4.98907000 & 0.58993000 & 0.79070200 \\
\hline $\mathrm{Cl}$ & -5.64598800 & 1.12203400 & -1.42545800 \\
\hline $\mathrm{Cl}$ & -6.72339900 & -0.96229000 & 0.38032900 \\
\hline $\mathrm{C}$ & 4.08171700 & 2.38836500 & -1.17144100 \\
\hline $\mathrm{H}$ & 4.89356000 & 3.07288700 & -1.43451900 \\
\hline $\mathrm{H}$ & 3.26163100 & 2.89577400 & -0.65074500 \\
\hline $\mathrm{Cl}$ & 4.72930200 & 1.14442700 & -0.07366700 \\
\hline $\mathrm{Cl}$ & 3.41973600 & 1.69838800 & -2.67257400 \\
\hline $\mathrm{Cl}$ & -2.68825400 & 0.38261200 & 1.76821200 \\
\hline Cs & 1.23963300 & -0.17235600 & -0.26195800 \\
\hline
\end{tabular}


22

$E=-5624.3643047$

\begin{tabular}{|c|c|c|c|}
\hline $\mathrm{N}$ & 0.20497000 & -1.38214700 & 2.35028400 \\
\hline $\mathrm{N}$ & 0.35219800 & 2.05014900 & 1.98432900 \\
\hline $\mathrm{N}$ & -0.89429500 & 1.76439000 & -1.24160700 \\
\hline $\mathrm{N}$ & -1.00863400 & -1.65604200 & -0.85045400 \\
\hline $\mathrm{C}$ & 0.59387200 & -2.56880600 & 1.77508700 \\
\hline $\mathrm{C}$ & 1.89847100 & -2.79893400 & 2.16611900 \\
\hline $\mathrm{C}$ & 2.29348100 & -1.71994400 & 3.00631200 \\
\hline $\mathrm{C}$ & 1.22213500 & -0.85426600 & 3.10854900 \\
\hline C & 1.09956800 & 0.47564300 & 3.83423800 \\
\hline $\mathrm{C}$ & 1.32494000 & 1.61353100 & 2.85251300 \\
\hline $\mathrm{C}$ & 2.45835000 & 2.36030300 & 2.59961500 \\
\hline C & 2.14787200 & 3.27540300 & 1.55467000 \\
\hline $\mathrm{C}$ & 0.83211200 & 3.06629200 & 1.19286000 \\
\hline $\mathrm{C}$ & -0.00599700 & 3.72653000 & 0.11124900 \\
\hline C & -0.03928200 & 2.83217200 & -1.11826200 \\
\hline $\mathrm{C}$ & 0.75607000 & 2.84489000 & -2.24842600 \\
\hline $\mathrm{C}$ & 0.35373700 & 1.75552400 & -3.07172800 \\
\hline C & -0.67823100 & 1.10165200 & -2.42585000 \\
\hline C & -1.46268400 & -0.13477600 & -2.83494000 \\
\hline $\mathrm{C}$ & -0.85785900 & -1.36828000 & -2.18518200 \\
\hline C & -0.07598800 & -2.36831900 & -2.72858600 \\
\hline $\mathrm{C}$ & 0.24560700 & -3.28181400 & -1.68165600 \\
\hline C & -0.34809000 & -2.81706800 & -0.52512400 \\
\hline $\mathrm{C}$ & -0.32367800 & -3.38927900 & 0.88341800 \\
\hline C & 2.17897900 & 0.54462600 & 4.92196200 \\
\hline C & -0.28254700 & 0.60531000 & 4.50158200 \\
\hline $\mathrm{C}$ & -1.42808100 & 4.00358700 & 0.62939100 \\
\hline $\mathrm{C}$ & 0.64386200 & 5.06266700 & -0.27064400 \\
\hline $\mathrm{C}$ & -1.38033100 & -0.28542700 & -4.35918000 \\
\hline C & -2.94134200 & 0.00265800 & -2.43694100 \\
\hline $\mathrm{C}$ & -1.74565800 & -3.42115300 & 1.47327900 \\
\hline $\mathrm{C}$ & 0.21105600 & -4.82551600 & 0.81917800 \\
\hline $\mathrm{H}$ & -0.70118700 & -0.92980900 & 2.19961300 \\
\hline $\mathrm{H}$ & -0.58936300 & 1.65485100 & 1.91499000 \\
\hline $\mathrm{H}$ & -1.58737700 & 1.49188600 & -0.54213900 \\
\hline $\mathrm{H}$ & -1.56684200 & -1.09804800 & -0.19525200 \\
\hline $\mathrm{H}$ & 2.50305800 & -3.66154400 & 1.89873800 \\
\hline $\mathrm{H}$ & 3.25639400 & -1.60518200 & 3.49711100 \\
\hline $\mathrm{H}$ & 3.41097700 & 2.27176700 & 3.11471800 \\
\hline $\mathrm{H}$ & 2.81910700 & 4.01621900 & 1.12869900 \\
\hline $\mathrm{H}$ & 1.53491300 & 3.56882800 & -2.47404800 \\
\hline $\mathrm{H}$ & 0.76863700 & 1.49572500 & -4.04221200 \\
\hline $\mathrm{H}$ & 0.19308300 & -2.45915700 & -3.77867000 \\
\hline $\mathrm{H}$ & 0.82109600 & -4.19976900 & -1.77411600 \\
\hline $\mathrm{H}$ & 3.18928400 & 0.45350500 & 4.49943900 \\
\hline $\mathrm{H}$ & 2.12040700 & 1.50605300 & 5.45154700 \\
\hline $\mathrm{H}$ & 2.04108400 & -0.27004600 & 5.64727400 \\
\hline
\end{tabular}




\begin{tabular}{|c|c|c|c|}
\hline $\mathrm{H}$ & -1.11065800 & 0.56804500 & 3.77876100 \\
\hline $\mathrm{H}$ & -0.43067500 & -0.21053600 & 5.22469700 \\
\hline $\mathrm{H}$ & -0.35179600 & 1.56434400 & 5.03583100 \\
\hline $\mathrm{H}$ & -2.02469600 & 4.50056600 & -0.14890800 \\
\hline $\mathrm{H}$ & -1.96712000 & 3.09048600 & 0.92079000 \\
\hline $\mathrm{H}$ & -1.38276000 & 4.66025900 & 1.51078200 \\
\hline $\mathrm{H}$ & 1.66853400 & 4.92830500 & -0.64405100 \\
\hline $\mathrm{H}$ & 0.05897500 & 5.55503200 & -1.06054000 \\
\hline $\mathrm{H}$ & 0.68809600 & 5.72639900 & 0.60466300 \\
\hline $\mathrm{H}$ & -0.34327800 & -0.39128900 & -4.70802500 \\
\hline $\mathrm{H}$ & -1.94051000 & -1.17418400 & -4.68342400 \\
\hline $\mathrm{H}$ & -1.81221000 & 0.60005000 & -4.84596900 \\
\hline $\mathrm{H}$ & -3.07490700 & 0.06854700 & -1.34832000 \\
\hline $\mathrm{H}$ & -3.37998600 & 0.90605500 & -2.88343900 \\
\hline $\mathrm{H}$ & -3.51090600 & -0.87254900 & -2.77999900 \\
\hline $\mathrm{H}$ & -2.18658800 & -2.41701200 & 1.54825600 \\
\hline $\mathrm{H}$ & -2.40772500 & -4.02384100 & 0.83513900 \\
\hline $\mathrm{H}$ & -1.72335200 & -3.85941600 & 2.48231500 \\
\hline $\mathrm{H}$ & 1.22638600 & -4.86426000 & 0.40008700 \\
\hline $\mathrm{H}$ & 0.24499000 & -5.26189200 & 1.82733300 \\
\hline $\mathrm{H}$ & -0.44108100 & -5.44580000 & 0.18776600 \\
\hline $\mathrm{C}$ & 5.76751000 & 0.55863700 & -0.32039100 \\
\hline $\mathrm{H}$ & 6.83019600 & 0.80108400 & -0.22446500 \\
\hline $\mathrm{H}$ & 5.59769100 & -0.21695700 & -1.07579500 \\
\hline $\mathrm{Cl}$ & 4.90395000 & 2.02495400 & -0.83690400 \\
\hline $\mathrm{Cl}$ & 5.19372700 & -0.06463600 & 1.24312800 \\
\hline $\mathrm{C}$ & -5.44050500 & 1.49840300 & -0.32227000 \\
\hline $\mathrm{H}$ & -6.13554400 & 1.79600300 & 0.46847700 \\
\hline $\mathrm{H}$ & -4.69319200 & 0.79322700 & 0.05992100 \\
\hline $\mathrm{Cl}$ & -4.57726700 & 2.95187400 & -0.88110500 \\
\hline $\mathrm{Cl}$ & -6.36966100 & 0.72249800 & -1.61840600 \\
\hline $\mathrm{C}$ & -5.09568900 & -1.85608500 & 1.55184600 \\
\hline $\mathrm{H}$ & -5.05161400 & -2.77243100 & 2.14920200 \\
\hline $\mathrm{H}$ & -4.31990400 & -1.13680600 & 1.84305400 \\
\hline $\mathrm{Cl}$ & -6.68572100 & -1.10278900 & 1.81106100 \\
\hline $\mathrm{Cl}$ & -4.80869800 & -2.29042700 & -0.14820900 \\
\hline $\mathrm{C}$ & 3.49142000 & -2.35052400 & -2.89144400 \\
\hline $\mathrm{H}$ & 3.99089800 & -2.99272200 & -3.62289000 \\
\hline $\mathrm{H}$ & 2.40667300 & -2.50427100 & -2.87481600 \\
\hline $\mathrm{Cl}$ & 3.79196700 & -0.65272000 & -3.33712400 \\
\hline $\mathrm{Cl}$ & 4.11423300 & -2.75016700 & -1.27306600 \\
\hline $\mathrm{Cl}$ & -2.36734200 & 0.35406000 & 1.34293800 \\
\hline Cs & 1.81793500 & 0.01663700 & -0.23139600 \\
\hline
\end{tabular}


23

$E=-6583.7456725$

\begin{tabular}{|c|c|c|c|}
\hline $\mathrm{N}$ & -0.37219500 & 0.33098200 & -2.61064500 \\
\hline $\mathrm{N}$ & -0.18482900 & 2.58598400 & 0.01103900 \\
\hline $\mathrm{N}$ & 0.40828600 & -0.03532900 & 2.21186000 \\
\hline $\mathrm{N}$ & 0.21165300 & -2.25783500 & -0.41828200 \\
\hline $\mathrm{C}$ & -0.99423400 & -0.82451800 & -3.02091700 \\
\hline $\mathrm{C}$ & -2.23480500 & -0.46300400 & -3.50886800 \\
\hline $\mathrm{C}$ & -2.34878300 & 0.95128200 & -3.39286600 \\
\hline $\mathrm{C}$ & -1.17553400 & 1.42214800 & -2.83574000 \\
\hline $\mathrm{C}$ & -0.76581200 & 2.83504200 & -2.45127700 \\
\hline $\mathrm{C}$ & -1.02744800 & 3.05282100 & -0.97004800 \\
\hline $\mathrm{C}$ & -2.09861300 & 3.64776500 & -0.33408300 \\
\hline $\mathrm{C}$ & -1.88335400 & 3.53795100 & 1.06833500 \\
\hline $\mathrm{C}$ & -0.68546100 & 2.87855600 & 1.25789400 \\
\hline $\mathrm{C}$ & 0.00627600 & 2.45389400 & 2.54269800 \\
\hline $\mathrm{C}$ & -0.28239800 & 0.98610200 & 2.81834600 \\
\hline $\mathrm{C}$ & -1.25121100 & 0.40196100 & 3.61168300 \\
\hline $\mathrm{C}$ & -1.12541500 & -1.00980800 & 3.47800500 \\
\hline $\mathrm{C}$ & -0.08258400 & -1.25695300 & 2.60603200 \\
\hline $\mathrm{C}$ & 0.47249700 & -2.57485600 & 2.08848100 \\
\hline $\mathrm{C}$ & -0.14857200 & -2.90223500 & 0.74016900 \\
\hline $\mathrm{C}$ & -1.13541000 & -3.80895000 & 0.40711000 \\
\hline $\mathrm{C}$ & -1.36510200 & -3.70080100 & -0.99652400 \\
\hline $\mathrm{C}$ & -0.51279300 & -2.73094800 & -1.48575700 \\
\hline $\mathrm{C}$ & -0.34623200 & -2.19375200 & -2.89803500 \\
\hline $\mathrm{C}$ & -1.61738000 & 3.82658100 & -3.25463100 \\
\hline $\mathrm{C}$ & 0.71738700 & 3.08098500 & -2.78418200 \\
\hline $\mathrm{C}$ & 1.52129200 & 2.69697700 & 2.44177900 \\
\hline $\mathrm{C}$ & -0.54636800 & 3.29306100 & 3.70184500 \\
\hline $\mathrm{C}$ & 0.11341600 & -3.68515100 & 3.08382600 \\
\hline $\mathrm{C}$ & 2.00438600 & -2.50608800 & 1.96383900 \\
\hline $\mathrm{C}$ & 1.14625500 & -2.10911900 & -3.26699600 \\
\hline $\mathrm{C}$ & -1.03672400 & -3.15459300 & -3.87436400 \\
\hline $\mathrm{H}$ & 0.54645500 & 0.37183700 & -2.16362300 \\
\hline $\mathrm{H}$ & 0.68603800 & 2.08022600 & -0.16342300 \\
\hline $\mathrm{H}$ & 1.16767800 & 0.09517600 & 1.54104900 \\
\hline $\mathrm{H}$ & 0.94377200 & -1.54361000 & -0.48239100 \\
\hline $\mathrm{H}$ & -2.97834400 & -1.13746200 & -3.92535800 \\
\hline $\mathrm{H}$ & -3.19567900 & 1.55661800 & -3.70539900 \\
\hline $\mathrm{H}$ & -2.94774100 & 4.12159700 & -0.81899200 \\
\hline $\mathrm{H}$ & -2.53683600 & 3.91592400 & 1.84994500 \\
\hline $\mathrm{H}$ & -1.96606700 & 0.92855800 & 4.23870800 \\
\hline $\mathrm{H}$ & -1.72556400 & -1.76051200 & 3.98561200 \\
\hline $\mathrm{H}$ & -1.61038300 & -4.50672700 & 1.09327300 \\
\hline $\mathrm{H}$ & -2.05342500 & -4.29653300 & -1.59154800 \\
\hline $\mathrm{H}$ & -2.69098100 & 3.69487900 & -3.06108000 \\
\hline $\mathrm{H}$ & -1.35089400 & 4.85905200 & -2.98748800 \\
\hline $\mathrm{H}$ & -1.44862200 & 3.68312000 & -4.33140500 \\
\hline
\end{tabular}




\begin{tabular}{|c|c|c|c|}
\hline $\mathrm{H}$ & 1.40092400 & 2.42301700 & -2.22846000 \\
\hline $\mathrm{H}$ & 0.89407800 & 2.91815300 & -3.85772400 \\
\hline $\mathrm{H}$ & 0.99198400 & 4.11614800 & -2.53578400 \\
\hline $\mathrm{H}$ & 2.01288400 & 2.42916000 & 3.38822800 \\
\hline $\mathrm{H}$ & 1.98705300 & 2.09587000 & 1.64934200 \\
\hline $\mathrm{H}$ & 1.72278300 & 3.75492200 & 2.21934400 \\
\hline $\mathrm{H}$ & -1.63049900 & 3.16162100 & 3.82292400 \\
\hline $\mathrm{H}$ & -0.06352100 & 2.99958200 & 4.64478900 \\
\hline $\mathrm{H}$ & -0.35409600 & 4.36014700 & 3.52087700 \\
\hline $\mathrm{H}$ & -0.97303700 & -3.78246900 & 3.21940300 \\
\hline $\mathrm{H}$ & 0.50000000 & -4.65103200 & 2.72815900 \\
\hline $\mathrm{H}$ & 0.55862800 & -3.46777000 & 4.06477700 \\
\hline $\mathrm{H}$ & 2.32587300 & -1.76294200 & 1.22172400 \\
\hline $\mathrm{H}$ & 2.46080800 & -2.23730300 & 2.92708500 \\
\hline $\mathrm{H}$ & 2.40621300 & -3.47808500 & 1.64420200 \\
\hline $\mathrm{H}$ & 1.70417200 & -1.43566900 & -2.60083600 \\
\hline $\mathrm{H}$ & 1.61442600 & -3.10099500 & -3.19155800 \\
\hline $\mathrm{H}$ & 1.25843500 & -1.73741300 & -4.29655600 \\
\hline $\mathrm{H}$ & -2.11016300 & -3.25501400 & -3.66044300 \\
\hline $\mathrm{H}$ & -0.93108600 & -2.78479600 & -4.90396600 \\
\hline $\mathrm{H}$ & -0.58155100 & -4.15312900 & -3.80837400 \\
\hline $\mathrm{C}$ & -6.05793200 & 1.09878500 & 0.48386800 \\
\hline $\mathrm{H}$ & -7.04148700 & 1.56969500 & 0.57392100 \\
\hline $\mathrm{H}$ & -6.13461000 & 0.00599400 & 0.46215400 \\
\hline $\mathrm{Cl}$ & -5.09270400 & 1.55339600 & 1.90678000 \\
\hline $\mathrm{Cl}$ & -5.32354600 & 1.62533200 & -1.04733900 \\
\hline $\mathrm{C}$ & 5.06744800 & -0.66773100 & 1.46265700 \\
\hline $\mathrm{H}$ & 5.90386300 & -0.14939000 & 0.98253100 \\
\hline $\mathrm{H}$ & 4.26082100 & -0.85323200 & 0.74514800 \\
\hline $\mathrm{Cl}$ & 4.41021300 & 0.39148300 & 2.73933600 \\
\hline $\mathrm{Cl}$ & 5.64066700 & -2.21712900 & 2.09936700 \\
\hline $\mathrm{C}$ & 4.80266500 & -1.43587400 & -2.08955500 \\
\hline $\mathrm{H}$ & 4.63977400 & -1.55677800 & -3.16508600 \\
\hline $\mathrm{H}$ & 4.31181200 & -0.53086600 & -1.70966800 \\
\hline $\mathrm{Cl}$ & 6.55046200 & -1.30653600 & -1.80121400 \\
\hline $\mathrm{Cl}$ & 4.07909200 & -2.83838500 & -1.26462800 \\
\hline $\mathrm{C}$ & -4.67742200 & -3.16836300 & 0.28669300 \\
\hline $\mathrm{H}$ & -5.40549700 & -3.98313900 & 0.34139300 \\
\hline $\mathrm{H}$ & -3.65032700 & -3.53376100 & 0.18109100 \\
\hline $\mathrm{Cl}$ & -4.76660300 & -2.23376100 & 1.79932300 \\
\hline $\mathrm{Cl}$ & -5.04626900 & -2.18035400 & -1.14706300 \\
\hline $\mathrm{C}$ & 4.45004600 & 2.84051300 & 0.17200000 \\
\hline $\mathrm{H}$ & 3.71270800 & 2.04865000 & 0.33535400 \\
\hline $\mathrm{H}$ & 4.94001300 & 3.14639000 & 1.10113200 \\
\hline $\mathrm{Cl}$ & 3.60141000 & 4.24656100 & -0.50607800 \\
\hline $\mathrm{Cl}$ & 5.68958800 & 2.17573200 & -0.91858000 \\
\hline $\mathrm{Cl}$ & 2.15151900 & 0.34943500 & -0.54080100 \\
\hline Cs & -2.24761400 & -0.04531900 & 0.13847100 \\
\hline
\end{tabular}




\begin{tabular}{|c|c|c|c|}
\hline \multicolumn{4}{|c|}{$\begin{array}{l}\mathrm{Cs}^{+}: \mathrm{CP} \\
E=-1326.5048013\end{array}$} \\
\hline $\mathrm{N}$ & 0.75318500 & -2.35597300 & 0.87350200 \\
\hline $\mathrm{N}$ & 2.35592900 & 0.75307700 & 0.87351900 \\
\hline $\mathrm{N}$ & -0.75307100 & 2.35598700 & 0.87398100 \\
\hline $\mathrm{N}$ & -2.35591600 & -0.75310800 & 0.87390600 \\
\hline $\mathrm{C}$ & -0.20457200 & -3.08779700 & 0.20553100 \\
\hline $\mathrm{C}$ & 0.39371600 & -3.57494700 & -0.93660900 \\
\hline $\mathrm{C}$ & 1.75294800 & -3.14132600 & -0.93626100 \\
\hline $\mathrm{C}$ & 1.95811300 & -2.39728000 & 0.20599400 \\
\hline $\mathrm{C}$ & 3.18279000 & -1.64050700 & 0.69300200 \\
\hline $\mathrm{C}$ & 3.08787500 & -0.20456200 & 0.20551300 \\
\hline $\mathrm{C}$ & 3.57511300 & 0.39389600 & -0.93649800 \\
\hline $\mathrm{C}$ & 3.14148500 & 1.75310800 & -0.93603100 \\
\hline $\mathrm{C}$ & 2.39737800 & 1.95814000 & 0.20621100 \\
\hline $\mathrm{C}$ & 1.64057200 & 3.18275500 & 0.69330700 \\
\hline $\mathrm{C}$ & 0.20460600 & 3.08781000 & 0.20586800 \\
\hline $\mathrm{C}$ & -0.39381300 & 3.57488800 & -0.93621700 \\
\hline $\mathrm{C}$ & -1.75301800 & 3.14127800 & -0.93571600 \\
\hline $\mathrm{C}$ & -1.95809100 & 2.39732100 & 0.20660000 \\
\hline $\mathrm{C}$ & -3.18272300 & 1.64060600 & 0.69366500 \\
\hline $\mathrm{C}$ & -3.08791400 & 0.20463600 & 0.20605500 \\
\hline $\mathrm{C}$ & -3.57528500 & -0.39369600 & -0.93594300 \\
\hline $\mathrm{C}$ & -3.14161000 & -1.75288800 & -0.93567100 \\
\hline $\mathrm{C}$ & -2.39731000 & -1.95803300 & 0.20640000 \\
\hline $\mathrm{C}$ & -1.64053600 & -3.18271300 & 0.69320000 \\
\hline $\mathrm{C}$ & 4.44291600 & -2.29089600 & 0.10657600 \\
\hline $\mathrm{C}$ & 3.27886200 & -1.68926600 & 2.22857200 \\
\hline $\mathrm{C}$ & 1.68940100 & 3.27878500 & 2.22887900 \\
\hline $\mathrm{C}$ & 2.29082900 & 4.44295400 & 0.10688900 \\
\hline $\mathrm{C}$ & -4.44295200 & 2.29083300 & 0.10728000 \\
\hline $\mathrm{C}$ & -3.27885600 & 1.68921100 & 2.22924000 \\
\hline $\mathrm{C}$ & -1.68904000 & -3.27914300 & 2.22875700 \\
\hline $\mathrm{C}$ & -2.29067900 & -4.44288100 & 0.10658900 \\
\hline $\mathrm{H}$ & 0.64052700 & -2.00540500 & 1.81363500 \\
\hline $\mathrm{H}$ & 2.00509200 & 0.64035500 & 1.81356800 \\
\hline $\mathrm{H}$ & -0.64039200 & 2.00551600 & 1.81417600 \\
\hline $\mathrm{H}$ & -2.00509100 & -0.64035100 & 1.81393900 \\
\hline $\mathrm{H}$ & -0.08262300 & -4.19619400 & -1.69092800 \\
\hline $\mathrm{H}$ & 2.50136900 & -3.37160200 & -1.69029500 \\
\hline $\mathrm{H}$ & 4.19642200 & -0.08232500 & -1.69083900 \\
\hline $\mathrm{H}$ & 3.37181800 & 2.50162000 & -1.68995400 \\
\hline $\mathrm{H}$ & 0.08244200 & 4.19608300 & -1.69063000 \\
\hline $\mathrm{H}$ & -2.50151400 & 3.37149800 & -1.68968900 \\
\hline $\mathrm{H}$ & -4.19673500 & 0.08258900 & -1.69012800 \\
\hline $\mathrm{H}$ & -3.37202200 & -2.50133300 & -1.68963600 \\
\hline $\mathrm{H}$ & 4.43267300 & -2.28338800 & -0.99164200 \\
\hline $\mathrm{H}$ & 5.33962100 & -1.74836700 & 0.43702600 \\
\hline $\mathrm{H}$ & 4.51838100 & -3.33710200 & 0.43384500 \\
\hline
\end{tabular}




$\begin{array}{lrrr}\mathrm{H} & 2.40954900 & -1.23941100 & 2.73862400 \\ \mathrm{H} & 3.35254100 & -2.73002100 & 2.57440400 \\ \mathrm{H} & 4.17028900 & -1.14625000 & 2.57328900 \\ \mathrm{H} & 1.14662100 & 4.17034100 & 2.57363300 \\ \mathrm{H} & 1.23934700 & 2.40957500 & 2.73892900 \\ \mathrm{H} & 2.73018600 & 3.35219700 & 2.57468300 \\ \mathrm{H} & 2.28311900 & 4.43281900 & -0.99132800 \\ \mathrm{H} & 1.74833400 & 5.33961300 & 0.43751900 \\ \mathrm{H} & 3.33709400 & 4.51841600 & 0.43397500 \\ \mathrm{H} & -4.43308500 & 2.28258900 & -0.99093800 \\ \mathrm{H} & -5.33962900 & 1.74865900 & 0.43837700 \\ \mathrm{H} & -4.51813000 & 3.33726900 & 0.43389200 \\ \mathrm{H} & -2.41094800 & 1.23672500 & 2.73933400 \\ \mathrm{H} & -3.34975500 & 2.73006900 & 2.57537400 \\ \mathrm{H} & -4.17185100 & 1.14859100 & 2.57365000 \\ \mathrm{H} & -1.23583200 & -2.41170400 & 2.73900400 \\ \mathrm{H} & -2.72991900 & -3.34931100 & 2.57498600 \\ \mathrm{H} & -1.14909800 & -4.17264400 & 2.57291600 \\ \mathrm{H} & -2.28210900 & -4.43296100 & -0.99162600 \\ \mathrm{H} & -1.74864800 & -5.33960100 & 0.43780100 \\ \mathrm{H} & -3.33721400 & -4.51800900 & 0.43289600 \\ \mathrm{Cs} & -0.00005400 & -0.00000300 & -1.58031500\end{array}$

